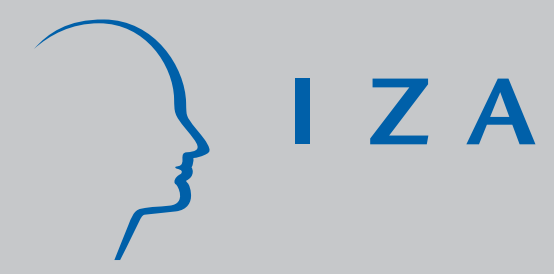

IZA DP No. 889

Fiscal Policy, Human Capital, and Canada-US Labor Market Integration

David E. Wildasin

October 2003 


\title{
Fiscal Policy, Human Capital, and Canada-US Labor Market Integration
}

\author{
David E. Wildasin \\ University of Kentucky \\ and IZA Bonn
}

\author{
Discussion Paper No. 889 \\ October 2003
}

\author{
IZA \\ P.O. Box 7240 \\ D-53072 Bonn \\ Germany \\ Tel.: +49-228-3894-0 \\ Fax: +49-228-3894-210 \\ Email: iza@iza.org
}

This Discussion Paper is issued within the framework of IZA's research area Internationalization of Labor Markets. Any opinions expressed here are those of the author(s) and not those of the institute. Research disseminated by IZA may include views on policy, but the institute itself takes no institutional policy positions.

The Institute for the Study of Labor (IZA) in Bonn is a local and virtual international research center and a place of communication between science, politics and business. IZA is an independent, nonprofit limited liability company (Gesellschaft mit beschränkter Haftung) supported by Deutsche Post World Net. The center is associated with the University of Bonn and offers a stimulating research environment through its research networks, research support, and visitors and doctoral programs. IZA engages in (i) original and internationally competitive research in all fields of labor economics, (ii) development of policy concepts, and (iii) dissemination of research results and concepts to the interested public. The current research program deals with (1) mobility and flexibility of labor, (2) internationalization of labor markets, (3) welfare state and labor market, (4) labor markets in transition countries, (5) the future of labor, (6) evaluation of labor market policies and projects and (7) general labor economics.

IZA Discussion Papers often represent preliminary work and are circulated to encourage discussion. Citation of such a paper should account for its provisional character. A revised version may be available on the IZA website (www.iza.org) or directly from the author. 
IZA Discussion Paper No. 889

October 2003

\section{ABSTRACT \\ Fiscal Policy, Human Capital, and Canada-US Labor Market Integration*}

This paper analyzes some of the implications of North American labor market integration for fiscal policy. The economies of Canada and the US are both characterized by highly integrated internal markets for goods and services as well as for labor and capital, and subnational governments in both economies play an important role in the financing and provision of public goods and services, including higher education. Despite theoretical insights from traditional trade theory that suggest that "trade and migration are substitutes", labor markets in both the US and Canada exhibit substantial and persistent interregional migration, with gross migration rates that greatly exceed net migration rates, especially for highly-educated workers. High gross migration rates are consistent with the hypothesis that education contributes to skill-specialization and worker heterogeneity, and that mobility provides a form of insurance for investment in risky human capital. Mobility also constrains the ability of competitive governments to engage in redistributive financing of human capital investment, and recent trends in both the US and Canada reveal a diminishing level of financial support for public-sector institutions by subnational governments. The implications of labor market integration for the efficiency of resource allocation, for income determination, and for fiscal competition are important for evaluations of tax and education policies both at the subnational and at the international levels.

JEL Classification: Jo, HO, F2, RO

Keywords: $\quad$ labor market integration, fiscal policy, mobility, human capital

David E. Wildasin

Martin School of Public Policy

University of Kentucky

Lexington, KY 40506-0027

USA

Email: wildasin@tanstaafl.gws.uky.edu

\footnotetext{
${ }^{*}$ An earlier version of this paper was presented at a conference on "Social and Labour Market Aspects of North American Linkages", sponsored by Human Resources Development Canada and Industry Canada, Montreal, October, 2002. I am grateful to especially E. Beaulieu, M. Lovely, P. Poutvaara, M. Streams, and conference participants for helpful comments, but retain responsibility for any errors.
} 
"[I]t is a little superfluous for any foreigner to come to Rotterdam to lecture about economics at all. I feel a bit like a 17th century New England smuggler lecturing on seamanship to Admiral Tromp... I suppose the logic of the situation is that I am not an import at all; I am to be processed and re-exported, like cocoa beans." R. M. Solow, on presenting invited lectures in Rotterdam (Solow [1963], p. 7).

\section{Introduction}

Liberalization of trade in North America has potentially important consequences for the functioning of labor markets and the development of human resources in this region. What are the implications of greater economic integration for earnings, earnings inequality, labor mobility, and human capital investment and financing? The objective of this paper is to help to clarify these issues conceptually, to discuss some of their empirical dimensions, and to suggest some possible implications for policy and for future research.

Integration of markets for (either, or both) goods and factors of production (defined, loosely, as a reduction in fundamental barriers to exchange due to broadly-defined technological change as well as reductions in barriers resulting from liberalization of policy) has complex effects because it changes the general equilibrium of the entire economy. Labor markets may be affected directly by technological changes that facilitate international migration, such as reductions in search and moving costs, or by policy changes such as those embodied in NAFTA that allow greater international mobility within North America for purposes of business or otherwise. They can also be affected indirectly by changes in trade policy, most obviously because of changes in the sectoral composition of demand and hence through resulting changes in demand for different productive inputs. Perhaps less obviously, changes in trade policy can lead to changes in the optimal organization of commercial activity, including changes in the size and scope of firms and the degree of vertical integration of the production process, leading in turn to changes in the deployment of managerial, technical, and scientific human resources across space, including across international boundaries. Because these effects are potentially highly inter-related, it is useful to consider the process of economic integration not only in terms of immediate impacts on particular markets, for example by examining the extent to which international migration flows change in the short run, or whether these flows affect or are immediately affected by wages or earnings, tax policy, or other specific variables, but also from a general equilibrium perspective that recognizes the inter-relationships among markets and among various spheres of policy. Furthermore, the effects of structural economic change does 
not occur instantaneously, and short-run effects can differ markedly from long-run effects.

As one simple illustration of these remarks, note that policies that change the rewards to more or less skilled workers - as NAFTA may well have done, according to studies cited below - change the incentives for skill acquisition. But the supply response to these incentives is complex and may well vary over time. For example, in the short run, many members of the existing work force are unlikely to upgrade their skills or change their occupational specializations. As a broad generalization, middle-aged and older workers lacking advanced training seldom have sufficiently strong incentives to divert the time and money needed to obtain university educations, mid-career physicists or nuclear engineers are not likely to have powerful incentives to change careers to become lawyers or accountants. The strength of these incentives depends partly on real income differentials and whether other supply responses - for example, international migration - limit the incentive to alter the human capital of the existing workforce. Over time, the supply response will reflect the entry of new workers into the labor force, including young people who, like their predecessors, make choices about the level and type of investment (whether to attend college, whether to study law, medicine, mathematics, or history) based on current and prospective market conditions. The supply response also depends on public policy adjustments, including not only the overall funding for education at all levels but adjustment, if required, in the types of instruction offered. In higher education, for example, employment regulations and traditions make it difficult to shrink the deployment of resources in some areas in order to expand the availability of resources in other areas. Similarly, capital flows across sectors within countries, and across international boundaries - also respond to, and influence, ongoing adjustments in the labor market. This adjustment process is also not instantaneous, and the dynamics of capital adjustment are likely to be highly inter-related with those of the labor market.

The full complexity of these interactions is obviously beyond the scope of any single analysis. The present discussion is intended to identify some significant elements of the process of economic integration with an eye to understanding some of their implications for the formation and utilization of human capital.

To begin with, Section 2 reviews some basic theory about linkages between trade and factor pricing. It is often suggested that liberalization of trade can "substitute" for geographic integration of factor markets. However, the conditions under which this is true are not always satisfied either within or among countries. It is important to understand the linkage between trade and migration because, as Section 3 shows, internal migration is a persistent feature of the US and Canadian labor markets. This section presents a very simple analytical framework which is helpful in understanding 
some of the allocative and distributional effects of internal migration. It also discusses the high levels of gross migration flows among regions within the US and Canada and the particular importance of mobility for highly-educated workers, suggesting that the spatial integration of labor markets is linked to the types of skill-specialization normally associated with higher education. Section 4 briefly reviews the US and Canadian experience with higher education finance, drawing attention to recent trends in the funding of higher-education institutions and to the changing roles of national and subnational governments, and of the private and public sectors in general. Section 5 discusses how the integration of factor markets affects the environment within which policy is made. Factor mobility means that regions must compete for human and other resources. Government fiscal policies affect the allocation of resources among regions, and, in particular, competition for highly-skilled workers can affect the structure of government revenue systems. Competition for mobile resources, along with several other factors, may help to explain some of the recent trends in higher-education finance, and may contribute to further evolution of policy in this area, as well as with respect to tax policy generally. The discussion concludes by noting several major research questions that await investigation and that are important for arriving at a more secure foundation for policy analysis.

\section{Theoretical Considerations: Trade and Migra- tion}

\subsection{Factor-Price Equalization: A Brief Recapitulation}

Analysis of the economic impact of international migration within the context of a broader process of economic integration must quickly come to grips with a powerful insight from traditional international trade theory: the factor price equalization theorem. According to this theorem, which is one of the textbook results of international trade theory, the opening up of international trade in goods and services should lead a country to expand its production in industries that rely heavily on inputs - capital, labor, natural resources - that are relatively cheap there, and to contract its production in industries that use intensively inputs which, in that country, are relatively costly. Because of their favorable cost structure, firms in the former industries will be able to compete advantageously against foreign producers, allowing the country to export those goods and services, whereas the reverse is true for the latter industries: these will be the industries in which imports from abroad will penetrate the domestic market, resulting in reduced employment, investment, and output. As this process 
occurs, expansion of the domestic export industries and contraction of the domestic import-competing industries will result in increased demand for those domestic inputs that are relatively cheap and reduced demand for those inputs that are relatively expensive. So, for instance, a country with abundant and therefore comparatively cheap high-skilled labor will expand production of goods and services that require such labor, relying on imports from abroad to meet the demand for goods and services that require low-skilled labor. As this happens, the earnings of high-skilled workers in the domestic market will rise, while the earnings of low-skilled workers will fall. The opposite occurs in other countries, driving up the earnings of low-skilled workers and reducing the earnings of high-skilled workers.

Under some assumptions, principally that countries have access to identical constantreturns-to-scale production technologies, that markets are perfectly competitive, and that factors of production can move freely from contracting to expanding industries, the process of trade should lead to complete international equality of relative factor prices - factor price equalization. Thus, for instance, the wage per unit of managerial services relative to the wage per unit of blue-collar services should be equalized. Similarly, the relative return per unit of capital services, the return per effective unit of land or natural resources, and other factor prices should tend to converge as trade expands. These are expected to be among the consequences of trade liberalization policies like NAFTA, or of other political or technological changes that reduce existing trade barriers.

The factor-price equalization theorem suggests that international trade affects the distribution of income. Correctly understood, however, factor-price equalization does not imply that the annual real income per manager or per blue-collar worker is equalized across countries. Managers or blue-collar workers in one country may embody more or fewer effective units of their respective skills than workers in another country. Factor price equalization implies (for example) that if low-skilled workers in one country are able to produce twice as many units of low-skilled services as workers in another country, their incomes will be twice as high. This presents a serious challenge for empirical research, since it is difficult to determine whether (for example) better-educated workers in one country have higher incomes because they embody more units of the same types of human resources as lower-skilled workers in the same country or whether the skills that they obtain through education are different and more highly-rewarded than those of less-educated workers. ${ }^{1}$

\footnotetext{
${ }^{1}$ Trefler (1993) emphasizes the importance of international differences in productivity and their relevance for explaining trade patterns and for testing for factor price equalization - a matter of considerable importance, since it is known that factor-price equalization can fail when production technologies differ. The discussion below is agnostic about differences in technologies among regions, but it should be noted that productivity-adjusted factor price equalization among regions is fully
} 
To formulate this distinction more precisely, suppose that production in a particular industry in country (or region) $j$ uses a combination of capital $k_{j}$, natural resources $n_{j}$, and several different types of labor $l_{i j}$, where $i=1, \ldots m$ indexes the labor type; for instance, labor high-skilled labor might be type-1 and low-skilled labor might be type $2 .^{2}$ With marginal-productivity factor pricing, and letting $p_{j}$ denote the price of the output of this industry, the wages for workers of type $i$ in the local labor markets are given by

$$
w_{i j}=p_{j} \frac{\partial f_{j}\left(k_{j}, n_{j}, l_{1 j} \ldots l_{m j}\right)}{\partial l_{i j}}
$$

where $f_{j}(\cdot)$, the level of industry output, depends not only on labor inputs but on other productive resources (capital, natural resources, etc.) as well. In general, the degree of substitutability between labor of different types can range from nil to complete. In the latter case, the wages of high- and low-skilled workers will differ only because they possess different quantities of skills which are effectively homogeneous - that is, they have different effective labor supplies.

It is worth noting that this special assumption of perfect substitutability - augmented with the further assumption that labor is the only factor of production so that the marginal productivity of labor is a technological constant - has been the basis of a large literature on optimal income taxation, beginning, in its modern form, with the seminal work of Mirrlees (1971). It also has been a maintained assumption in many traditional macro growth models, in which, for instance, capital and labor are treated as the only two inputs in the aggregate production function. In this context, labor is not treated as the sole input and the degree of substitutability between labor and capital is one of the important parameters of the model; customarily, an elasticity of substitution of one (the Cobb-Douglas case) or less is thought to fit the data best. In this respect, growth models offer a richer framework for the analysis of income distribution because they distinguish between labor and non-labor income. However, in models where all labor (and labor supply behavior) is homogeneous, changes in earnings inequality must ultimately be traced to changes in the distribution of the amount of effective labor services within the working population. In this context, for instance, an increase in earnings inequality during the 1990s could be attributed to some combination of an augmentation of the skills of high-skill workers ("experience", or on-the-job training) and a reduction in the skills of low-skill workers ("depreciation" of human capital for these workers). A more plausible explanation for changes in the distribution of earnings, however, is that workers of different types are not perfect

consistent with the possibility that workers (or other factors) can increase their incomes by moving from low- to high-productivity regions.

${ }^{2}$ Each of these input variables may interpreted, if desired, as a vector, thus allowing for any number of productive inputs. 
substitutes for one another, at least in the "short run" during which worker skill levels are treated as exogenously fixed.

In any event, whether or not different types of labor are perfect substitutes, workers of the same type in different countries are perfect substitutes, by definition. With free trade and given the other assumptions of the factor-price equalization theorem, the wage rates of these workers should be the same across countries. In this case, international differences in earnings per worker of a given type must be attributed to differences in the effective number of units of labor supplied per worker across countries. Once again, this raises thorny issues for empirical analysis since it is difficult to determine whether workers with different earnings embody different amounts of the same type of labor or different types of labor.

While the factor-price equalization theorem is most commonly referenced in the context of international trade, it should be noted that it can be applied, as well, within countries. Indeed, trade within countries is often fundamentally less costly, and less impeded by restrictive policies, than trade among countries. In this context, the theorem implies that free trade among regions within a country should result in equalization of factor prices among regions. Internal migration is discussed further below.

\subsection{Trade and Migration: Substitutes or Complements?}

A famous analysis by Mundell (1957), drawing on classical Heckscher-Ohlin-Samuelson trade theory, argues that trade and factor mobility can be substitutes for one another. The essence of the argument derives from the factor-price equalization theorem: if trade tends to drive factor prices in different countries or regions closer together, and if factor reallocations across space are driven by factor price differentials, then trade can reduce or substitute entirely for factor movements. The rationale for this argument should be apparent from the foregoing remarks. The economic theory of factor movements across space rests on the fundamental hypothesis that factor owners - workers, in the case of human resources - seek the highest attainable net returns for the resources that they own. ${ }^{3}$ Real differences in net rates of return across regions create incentives for arbitrage, with workers or capital flowing from places where net rates of return are low to places where they are high. ${ }^{4}$

\footnotetext{
${ }^{3}$ See, e.g., Bauer and Zimmermann (1999) for a recent overview of theoretical and empirical analysis of migration.

${ }^{4}$ The "net rates of return" to which factor owners respond should be interpreted carefully: in cases where factor movements are not costlessly reversible, the rates of return in question should be understood to be expected utilities over the relevant (possibly endogenously-determined) decision
} 
The applicability of this analysis is limited, however, for several reasons. Perhaps most importantly, at least for present purposes, it neglects the spatial structure of factor markets within countries, which are effectively treated as single points in space. ${ }^{5}$ When trade occurs, factors of production are reallocated away from contracting industries in import sectors and toward expanding industries in export sectors. But in standard trade theory models, these factor reallocations do not occur among spatiallyseparated regions since countries - the geographical units of analysis in the standard model - have no spatial structure. In reality, of course, factor reallocations among industries within countries do involve spatial reallocations. The most obvious historical example is the process of urbanization, associated with the development of modern manufacturing industry and the movement of population from rural to urban areas. The intersectoral reallocation of productive resources that accompanies international trade is also, ordinarily, an inter-regional reallocation of resources, as well.

These observations are worth bearing in mind when considering intranational movement of labor and capital. They can help to explain why countries like the US and Canada are characterized both by liberal conditions for internal trade (there are no explicit tariffs on interprovincial or interstate commerce, nor are regulatory impediments allowed, generally, to interfere with free internal commerce) and by high levels of internal factor flows, as discussed further below.

Nevertheless, the basic insight that trade affects factor prices is a crucial one. When applied to human resources, it implies that the return to investment in human capital is affected by trade: countries that export commodities that are human-capital intensive and import those that can be produced with relatively small amounts of skilled labor, for example, should experience widening wage differentials between more-skilled and less-skilled workers. In recent years, a number of empirical analyses (see further discussion below) have attempted to find an explanation for increased dispersion of wages within the US and Canada, and it appears that a consensus has formed that "trade", broadly speaking, helps to explain a significant portion, though not all, of the widening of wage differentials within these countries.

horizon, appropriately adjusted for taxes, benefits from public goods and services, environmental, cultural, and other amenities, regulatory treatment, etc. Only in the simplest cases does this reduce to equalization of instantaneous pecuniary factor returns.

${ }^{5}$ This is a characterization of the standard theory, in its pure form. Of course many authors have varied the standard model in order to capture spatial factors. The specific-factors model can be interpreted in the context of geographically-fixed inputs; other studies distinguish regions within countries and analyze the implications of transportation costs and trade barriers for regions within countries; a notable example, relevant for the Canadian case, is Melvin (1985). More recently, Helliwell (1998) discusses internal and external trade at length and provides many more references to relevant literature. 


\section{Internal Migration in the US and Canada}

This section considers the role of internal migration in the US and Canada. The economies of both countries span large geographical areas and are characterized by a high degree of integration of internal markets for goods and services. In view of the theoretical considerations discussed in Section 2, it is natural to ask whether free internal trade has obviated any important economic role for internal migration in these two countries.

As we shall see, labor migration has, on the contrary, historically played a large role in the economies of the US and Canada, and this important role shows no signs of diminishing over time. Much internal migration takes the form of "cross-hauling" of labor, that is, of two-way labor flows among regions. In order to understand the economic implications of labor mobility and labor market integration, it is important to develop theoretical explanations for why such migration flows might be observed. The discussion below emphasizes the potential role of migration as a mechanism for spatial matching of the supply of and demand for specialized, heterogeneous labor skills.

\subsection{Intersectoral and Spatial Reallocation of Labor}

The extent to which "trade and migration are substitutes" can be considered not only in the context of international trade but within the context of trade within a country. Indeed, if trade within a country is free and if the other assumptions underlying the factor-price equalization theorem are satisfied, it would follow that internal migration or capital movements would be economically irrelevant, except insofar as workers have residential preferences that would motivate them to move from one region to another. In such an economy, a complete prohibition on inter-regional factor movements would affect neither the distribution of income nor the efficiency of resource allocation. In fact, this logic can be extended down to the lowest level of spatial analysis, leading to the conclusion that factor movements are always irrelevant so long as the assumptions of the factor-price equalization theorem are satisfied.

This reductio ad absurdum draws attention to an implicit assumption in most treatments of the factor-price equalization theorem. While it is explicitly acknowledged that factor-price equalization requires free intersectoral mobility of factors of production, this, in practice, presupposes free spatial mobility of factors. As one classic illustration of practical importance, consider the gradual shift of production and of 
productive resources from agriculture toward manufacturing (and more recently toward services) in the Canadian and US economies during the past century. Whereas $21.0 \%$ of employed workers in the US workforce were engaged in agriculture in 1939, that percentage had fallen to $2.3 \%$ by 2001 . This employment shift has been accompanied by rural-urban migration and increased urbanization of the population. For example, $39.6 \%$ of the US population lived in urban areas in 1900, with the remainder in rural areas, $56.1 \%$ were urbanized by 1940 , and, by $1990,75.2 \%$ of the population lived in urban areas. Canadian statistics tell a similar story. For example, in 1871, $25.6 \%$ of the Canadian population lived in urban areas; by 1901, this figure had risen to $37.4 \%$; in 1941, 54.3\% of the population was urbanized, and by 1996 the urban population had increased to $77.9 \%$ of the total. As in the US case, growing urbanization was accompanied by intersectoral shifts of labor away from agriculture. In 1881, $48.1 \%$ of the workforce was engaged in agriculture, a figure that fell to $40.2 \%$ in 1901, to $25.8 \%$ in 1941 , and, by 1996 , to $3.3 \%$.

More generally, labor and capital mobility - spatial as well as, and as part of, intersectoral resource mobility - have been of critical importance in the economic development of both the US and the Canadian economies throughout their histories. Trade within these economies has of course been subject to some restrictions due to regulatory and other policies (as has been true as well of the mobility of labor and capital), but both economies stand out, by world and historical standards, for their high degree of internal free trade over large geographical areas. Their experience provides strong evidence to suggest that trade and factor mobility are not highly substitutable but in fact can coexist for long periods of time.

\subsection{Modeling Internal Migration}

Why is internal migration a persistent feature of the Canadian and US labor markets? No doubt many factors are at work, but the natural starting point for analysis and a standard one, in the literature (see, e.g., Topel (1985)) - is to suppose that internal migration is driven by the desire of migrants to achieve higher levels of real income. The real income enjoyed by a worker in a region depends first and foremost on employment conditions there, for which real wages provide a convenient summary indicator.

As discussed previously, the assumptions of the factor-price equalization theorem must be invalid for wages to differ among regions within a country. Empirically, it is wellknown that real wages can, indeed, differ among regions for specific types of labor. For example, prolonged net East-West migration in the US (essentially during the entire 
20th century) has resulted in significant reallocation of labor from relatively low-wage to relatively high-wage regions. The "great migration" of black workers from the southern US to northern and midwestern cities during the period 1930-1960 reflects a movement from low-wage agricultural employment to higher-wage manufacturingsector jobs. These major trends demonstrate the existence of real wage differentials and their fundamental importance for major demographic shifts through internal migration. They suggest that the productivity of labor of specific types can vary over time and among regions because of technological change (e.g., changes in cotton-harvesting technology) and because of changes in domestic or world demand conditions that affect prices, desired output levels, and associated derived labor demands. Diminishing returns to labor inputs within a geographic area can arise because of the presence of locationally fixed or quasi-fixed factors. These include land and other natural resources, but also the stock of public infrastructure (highway systems, port facilities, water/gas/electricity distribution networks) which, even if variable in the long run, is often very slow to change. Some types of private fixed capital investments are also quite long-lived, as are quasi-public entities like major educational institutions and related research centers.

The presence of fixed or quasi-fixed inputs in the production process has far-reaching implications for the allocation of labor and the determination of wage rates. A simple and familiar diagrammatic illustration can convey the main points. Let the horizontal axis of Figure 1 measure the quantity of labor of a particular type $i$ in a particular region $j$; for simplicity, and without loss of important generality, assume that each worker inelastically supplies one unit of labor, so that the quantity of labor is equivalent to the number of workers of the specified type. Suppose that the region in question is small, relative to the rest of the domestic economy, in the sense that an increase or decrease in employment in this region has only a small impact on the real incomes of workers of this type in the rest of the economy, given by $w_{i}$ in the figure. The demand for labor of type $i$ in region $j$, as given in (1), depends on the amounts of other inputs in the region, the technology of production, and the price of the output produced by these workers, all of which, in general, vary over time. ${ }^{6}$ Let $l_{i j}$ denotes the number of workers initially located in the region. If migration into or out of the region is costless, then the region will experience immigration or emigration of workers of type $i$ depending on the values of local demand determinants. If migration is impossible (infinitely costly), then local demand conditions will determine the equilibrium local wage.

\footnotetext{
${ }^{6}$ The amounts of other variable inputs depends on their prices, and thus the demand for type- $i$ labor depends on other input prices as well as on the quantities of other fixed inputs. Assuming that the region is small in all relevant markets, the prices of other inputs are parametrically given and thus can be subsumed within the other data of the problem.
} 
Figure 1 illustrates two possible situations, one with high demand for type- $i$ labor, represented by $D_{i j}^{+}$, and one with low demand, represented by $D_{i j}^{-}$. These demands may reflect different values of output prices on world markets, different degrees of protectionist trade policies (e.g., a tariff on imports of the goods produced with type- $i$ labor in the high-demand case, free trade in the low-demand case), different states of technology, or different levels of complementary inputs such as public or private capital investment. When labor is costlessly mobile, the equilibrium quantity of employment reflects local demand conditions, shown as $l_{i j}^{+}$and $l_{i j}^{-}$in the figure. The difference between local demand and the initial endowment of labor $l_{i j}^{+}-l_{i j}$ represents net immigration of type- $i$ labor in the high-demand state, while $l_{i j}-l_{i j}^{+}$represents the outflow of this labor type in the low-demand situation. The equilibrium wage is fixed at $w_{i}$ by external market conditions, independently of the level of local demand. When labor is completely immobile, the equilibrium level of employment is fixed at $l_{i j}$ and no migration can occur, but the equilibrium local wage rate varies with local demand, for example from $w_{i j}^{+}$in the high-demand situation to $w_{i j}^{-}$in the low-demand situation.

This simple diagram illustrates the crucial role of fixed or quasi-fixed inputs in giving rise to diminishing returns to labor in a particular location, and in showing how factor mobility, in this case the mobility of labor, plays a crucial role in the equalization of factor prices among regions. Of course, migration costs may limit the extent to which local employment responds to varying local demand conditions - as indeed is illustrated most clearly in the case where migration costs are so high as to be prohibitive. In this case, local wages vary in accordance with local labor market demand conditions, rather than being determined entirely by external market conditions. But to the extent that labor can move among regions, wages - or, to be more accurate, real incomes - will tend to be equalized across space.

Note from this simple analysis that labor mobility contributes to the efficiency of resource allocation because workers move toward regions where they are more productive and away from regions where they are less productive. Labor mobility, in other words, is productivity enhancing. This point is well-known. For example, Hamilton and Whalley (1984) use a CGE model of the world economy in which labor is treated as a homogeneous factor of production. They estimate that free international mobility of labor would increase world output and real income by an amount approximately equal to world GDP. To this writer's knowledge, a similar calculation has not been made to illustrate how much labor mobility has contributed to the growth of US or Canadian GDP, although, in principle, this is not a difficult exercise. There is every reason to think that labor mobility makes a major contribution to the efficient functioning of North American labor markets, especially when the heterogeneity of labor 
is taken into account. ${ }^{7}$

\subsection{Internal Migration: Why Are Gross Flows So Large?}

While net migration among regions or countries is often a focus of attention for policymakers and analysts, the net movement of labor among regions in the US and Canada are the results of gross flows in opposite directions that are often much larger - frequently, by an order of magnitude - than the net flows.

Tables 1-3 draw on recent Canadian census data. Table 1 shows 5 -year migration by province and for the country as a whole, for the Census years of 1991 and $1996 .^{8}$ Table 2 presents the same data, expressed as percentages. Table 3 presents 1-year migration levels and rates for 1996 alone.

Looking first at the data in Tables 1 and 2 for 1996, we see that $43 \%$ of Canadians "moved", i.e., changed addresses, during the period 1991-1996. Many of these movers, however, stayed in the same municipal area (strictly, Census subdivision, CSD), and hence are classified as "non-migrants". Most of these non-migrants presumably changed residences but, if in the workforce, continued to participate in the same local labor market. "Migrants", on the other hand, lived in different municipal areas, or outside of Canada, 5 years previously; of these, approximately $3 \%$ lived in a different province and thus are classified as inter-provincial migrants. This means that gross inter-provincial migration, i.e., the sum of in- and out-migration for all provinces excluding international migration, amounted to $6 \%$ of the national population. The amount of migration varies substantially by province; unsurprisingly, in-migration to the two largest provinces, in absolute terms, was larger than for any other provinces but was comparatively modest in proportional terms, amounting to only $1-3 \%$ of the provincial population; corresponding figures for other provinces were generally in the $5-7 \%$ range. One would expect, of course, that the larger provinces would exhibit

\footnotetext{
${ }^{7}$ Topel (1986) shows that migration behavior is largely explained by the prospect of higher earnings. Topel (1991) shows that job mobility (i.e., job changes) accounts for a significant part of earnings growth over the life cycle. Job mobility is not identical to migration, but is certainly correlated with it. An analysis that links migration to earnings growth over the life cycle would provide considerable insight into the productivity gains generated by migration, and could provide the basis for an estimate of how much productivity and income the US or Canadian economies would lose if internal migration were curtailed.

${ }^{8}$ For further discussion and analysis of interprovincial migration by both native and immigrant Canadians, see Edmonston (2002). Edmonston finds that immigrants to Canada have higher rates of interprovincial migration than native Canadians, but that their migration patterns are otherwise broadly similar to natives.
} 
lower levels of interprovincial migration on account of their size. It is noteworthy, for example, that the proportion of all "migrants" in Ontario and Quebec are quite close to the national average, and that intraprovincial migration rates were relatively high for these two provinces; less-populous provinces generally exhibit higher rates of interprovincial migration and lower rates of intraprovincial migration.

The data for the 5-year period 1986-1991 are broadly similar but reveal somewhat higher levels of population movement than in the more recent period. Once again, while interprovincial migrants account for a comparatively small fraction of the populations of Ontario and Quebec, the total share of migrants in these provinces is quite close to the national average, again reflecting their large size. Both in 1991 and 1996, immigration from outside the country was about as large as the total amount of interprovincial migration.

Table 3 presents similar figures for 1996, but now showing only the amount of migration that occurs within a single year. All of the figures in this table are of course significantly smaller than for the 5-year data in Tables 1 and 2. Qualitatively speaking, however, the one-year data are generally similar to those in the 5-year tables.

Tables 4 and 5 present data on migration in the US. In this case, the data are presented at the level of the four Census regions, each region including a number of individual states. The total populations of these regions are approximately 2-3 times the size of the total Canadian population. These tables present data on annual migration flows for selected years, and are therefore perhaps most comparable to Table 3 . These figures reveal that the US is also characterized by a high level of internal migration. In this case, the data explicitly separate in- and out-migration, as well as reporting net migration flows. Annual in- and out-migration rates are generally in the range of $1-1.75 \%$, with gross migration rates (i.e., combined in- and out-migration rates) generally ranging from $2-3.25 \%$. Net migration rates must of course be smaller, by definition, than gross migration rates, but the data in Table 5 show that the magnitude of the difference is quite substantial: gross flows often exceed net flows by a factor of 10 or more, and in almost no cases exceed them by less than a factor of 4 .

In the US as in the Canadian case, these data could be reported at different levels of spatial aggregation, such as at the level of states or metropolitan areas. As one moves to smaller spatial units, migration rates rise. For example, in 1999-2000, a total of $16.0 \%$ of the US population changed location; of these, only $0.6 \%$ were movers from abroad, $6.3 \%$ moved from one state to another, $9.0 \%$ moved to a different county within the same state, and $9.0 \%$ moved from one place to another within the same county. For the same year, the nation's metropolitan areas experienced internal inmigration of 2.0 million people, out-migration of 1.9 million, net internal in-migration 
of .1 million, and immigration from abroad of 1.6 million. Note, again, that net internal migration is very small relative to gross migration flows. No doubt much (but not all) relocation at the most disaggregated level (within counties) is accounted for by changes in residence rather than by changes in employment, and even at the level of census regions a certain proportion of moves may involve no change in employment. Nevertheless, it is evident from these data - which, as in the Canadian case, reflect long-standing migration patterns that have persisted at least since World War II that there are high levels of internal migration in the US that involve changes either in employment status (school to work, work to retirement, etc.) or in location of employment. Furthermore, and very importantly, the high levels of gross relative to net migration reveal that there is a great deal of "cross-hauling" of labor: workers in the "East" move to the "West" while workers from the "West" move to the "East".

The high levels of gross internal migration in the US and Canada show convincingly that free internal trade has not eliminated internal migration. In addition, they suggest that labor cannot be accurately characterized as a homogeneous factor of production over time horizons of years or decades. Large and largely offsetting flows of labor into and out of local labor markets is indicative of a sorting or matching process in which workers search for and find "better" - i.e., higher-productivity and higher-real-wage jobs in other markets, a process which inevitably involves search and relocation costs that could be avoided if existing workers in local markets filled these jobs. The fact that this does not occur means that local workers are less satisfactory matches for local jobs, in many instances, than workers from other regions. ${ }^{9}$ In turn, this implies that "large" labor markets are productivity enhancing.

\subsection{Gross Migration and Skill Specialization}

Of course, mobility is not equally productivity-enhancing for all workers. Empirically, highly educated workers (especially young ones) migrate with greater frequency than lower-skilled workers. This has long been known in the literature. For example, Ehrenberg and Smith (1988, p. 360) observe that age is the most important determinant of migration, with young people moving more than old, and that "education

\footnotetext{
${ }^{9}$ Alternatively, the US and Canadian economies are characterized by a large and persistent volume of costly and wasteful migration. Wildasin and Wilson (1996) develop a model in which local governments, acting in the interests of owners of immobile local resources (e.g., property owners) pursue policies that generate such migration in equilibrium. As noted in that analysis, profit-maximizing firms might well pursue wage policies that produce inefficient labor turnover in order to exercise dynamic "monopsony power". This argument does not, however, provide a convincing explanation for "long distance" relocation of workers.
} 
is the single best indicator of who will move within an age group. ... [C]ollege education ... raises the probability of migrating the most" (emphasis in original). A number of recent studies examine the movement of highly-educated workers. Bound et al. (2001) find that states with higher-educational institutions that produce many educated graduates may employ such workers at a somewhat higher rate than other states, but that the rate of employment of highly-educated workers is not strongly linked to the number of such workers produced in a state. Kodrzycki (2001) finds that college graduates are more mobile than others, as expected, and that net migration of such individuals is substantially smaller than the amount of gross migration. For example, as shown in Table 6 , whereas over $6 \%$ of those with at least a college-level education move among Census Divisions (which divide the US into 9 areas) each year, the corresponding figure is just over $4 \%$ for high-school graduates and even lower for those with less than a high-school education. The figures in Table 7 show that about $25 \%$ of college graduates move across Census Divisions within a 5-year period, with gross migration flows that are much higher than net flows. Interestingly, this is true whether migration is defined relative to high school location (presumably an indicator of "home" region) or relative to college location (which, for some people, might be a "sojourn" away from a home region), indicating that job-related moves are indeed of considerable importance for highly-educated people.

Given the higher degree of specialization that is normally associated with high levels of education, this is perhaps not surprising. To take an example from higher education in economics, a university that seeks to hire a faculty member to teach (say) monetary economics may search over a large geographic area, possibly the entire world, in order to find a candidate with the desired skill attributes. Hiring a labor economist from a nearby university might save some moving costs, but a labor economist is not a good substitute for a monetary economist. In fact, a university that hires a monetary economist from another, distant university may at the same time find that another distant university, or perhaps even the same one, will successfully recruit a faculty member from its own history or physics department. The net migration flows among universities in a given year may thus be rather modest even while significant gross migration occurs. The explanation for the "cross-hauling" of labor, in this case, is to be found in the fact that employers are seeking workers to meet quite specialized demands, and that workers that can perform the required specialized tasks are not good substitutes for each other.

The notion that specialization is related to the size of a market is well known in economics (Smith, 1776, Book I, Chapter 3). Perhaps most commonly, economic analysis has focused on the size of goods markets (e.g., Stigler (1951)) and its implications for industry structure, but the size of factor markets can in principle be important 
as well. The "size" of a labor or capital market may be defined in different ways; presumably, the key characteristic of a "large" market is the presence of numerous buyers and sellers, and, as pointed out by Krugman (1991) and others, the creation of large markets may be one of the important forces behind agglomerative forces leading to urbanization. However, the observed continuing migration flows of highly-skilled workers in offsetting directions indicates a possible link between specialization of workers and labor markets that are large in a spatial sense. Indeed, it is quite possible that specialization in goods and services markets is complementary to specialization in the acquisition of skills, especially those skills that are acquired early in life involving investments in human capital that are not readily reversible.

To illustrate this idea, consider the decision to invest in highly specialized medical training and facilities, such as those needed to carry out kidney-pancreas transplants. According to the Scientific Registry of Transplant Recipients (2001), a total of 911 kidney-pancreas transplants were undertaken in the US in 2000. These procedures were performed at a total of 91 different facilities throughout the country, but only 30 of these facilities performed 10 or more. There were 4 facilities in California at which 10 or more transplants were performed; in no other state were there more than 2 such facilities. ${ }^{10}$

There are many risks associated with the assembly and utilization of the productive resources needed to provide such specialized medical services. Those who invest nonhuman capital in specialized medical facilities of this type clearly take some risk, since the ability to staff and utilize such a facility "profitably" over the investment planning horizon cannot be guaranteed. ${ }^{11}$ Many of the risks confronting these investors can, however, be pooled through financial markets, within the organizational structure of a hospital or consortium of health-care providers, or by other means, thus reducing the cost of these risks and their deterrent to undertaking investment in the first place. ${ }^{12}$

Because many institutions exist to help manage the risks facing those who invest nonhuman capital in specialized uses, the cost of these risks may be relatively small. By comparison, individuals contemplating investment in the human capital required to work at very specialized tasks face potentially much more costly risks, since their life-

\footnotetext{
${ }^{10}$ The most performed at any one location was 47; those performing 10 or more accounted for 553 , or approximately $60 \%$, of all such procedures. Kidney transplants are considerably more common than combined kidney-pancreas transplants, which in turn are more common than transplantation of the pancreas alone. In these other cases, as well, a large proportion of procedures are carried out at comparatively few locations.

${ }^{11}$ Even not-for-profit institutions face at least a long-run survival or break-even constraint.

${ }^{12}$ One of the risks facing those who invest in specialized medical facilities - that of not being able to staff the facility adequately - is mitigated, to some degree, by the option to engage in nation-wide or even international search for new or replacement personnel.
} 
time earnings streams cannot readily be insured. The ability to relocate may help to reduce some of this costly risk. For example, suppose that a pancreas-kidney transplant specialist's first job is at a transplant center in (say) Missouri. Conceivably, this will be the best possible lifetime employment match for this specialist. Over a working lifetime of three or four decades, however, the possibility exists that local employment conditions could deteriorate (perhaps the transplant center is mismanaged, funding is inadequate, or local regulatory policies become excessively burdensome) or that new and better opportunities could arise somewhere else. In the case of this specialized form of medical practice, as we have seen, "somewhere else" usually means "in a different state" (or country). For these and other specialized workers, restrictions on geographic mobility can magnify costly lifetime earnings risks. ${ }^{13}$ Similarly, the opportunity to search for job opportunities in a large market over the entire life cycle affects incentives for workers to develop their human capital over time. For instance, the prospect of searching for new jobs in a large market raises the incentive for medical (or other) specialists to hone their technical skills on an ongoing basis in occupations where their skills might otherwise depreciate rapidly because of rapid technological change. It can also provide an incentive to acquire managerial and organizational skills that may well be of greatest value in organizations elsewhere, either at "startup" facilities that need to assemble an entire team or at existing ones that look to the outside market for "fresh blood."

For these and other reasons, the possibility of participating in a large, geographicallydispersed market affects the incentives to acquire, maintain, develop, and utilize specialized skills. The timing and frequency with which any individual will find it advantageous to exercise the "exit option" may depend on many idiosyncratic factors, but a life-cycle pattern of employment characterized by occasional job switching and relocation would arise naturally in such an environment. ${ }^{14}$

The efficiency and distributional consequences of the workings of integrated labor markets are, in principle, rather complex. Most fundamentally, however, integrated labor

\footnotetext{
${ }^{13}$ A specialized worker with few outside employment options may confront monopsony exploitation, which, properly speaking, is not a risk but a type of hold-up problem (cf. Wildasin-Wilson (1996)). Intersectoral competition for young workers would still require the monopsonist to offer a lifetime earnings stream that is as attractive as any alternative. But the same basic obstacles to the insurance of lifetime earnings - costly verification/moral hazard as well as prohibitions on indenture - mean, in practice, that an irreversible investment in specialized skills faces a riskier return over the life cycle when the range of future employment opportunities is narrow.

${ }^{14}$ Riddell and Sweetman (1999), analyzing a sample of Canadian workers, find that there is a substantial earnings premium for workers who assert that their job is "closely related" to their field of study. This suggests that workers whose specialized skills are well-matched with their employment are more productive and that there is a substantial loss of productivity associated with working in jobs that do not utilize specific skills.
} 
markets contribute to (i) more efficient utilization of the existing stocks of specialized human capital, (ii) reduced costs of risk associated with investment in the acquisition of specialized skills, and thus (cet. par.) (iii) greater incentives to invest in such skills. ${ }^{15}$ A reduction in risk, ex ante, corresponds to a reduction in inequality within skill groups, ex post. The overall distributional effects of greater market integration, such as the impact on the relative earnings of high- and low-skilled workers, on the returns to immobile natural resources, or on the return to capital, are much more difficult to ascertain.

Many of these ideas are easily illustrated using Figure $1 .{ }^{16}$ Suppose that the two demand curves shown there represent the future demand for specialized labor of type $i$ in region $j$ in different states of the world. For example, consider a young person who has acquired specialized legal training in the field of intellectual property rights (labor of type $i$ ) and is initially employed in New York City (region $j$ ). In the future, demand for this person's particular skills may be very high in New York City, but it may also be relatively low as greater demands arise in other locations, e.g., Washington, DC (home of the Patent and Trademark Office), Silicon Valley, Redmond, Washington, or Research Triangle Park in North Carolina. If workers of this type could not move freely between New York and other locations, their specialized skills would produce high earnings $\left(w_{i j}^{+}\right)$in high-demand states of the local labor market but low earnings $\left(w_{i j}^{-}\right)$in other cases - i.e., future earnings would be risky. For the employers of such workers, incomes would also, in general, vary with the state of the world. As Figure 1 happens to be drawn, with demand curves that differ among states of the world solely by a vertical shift, the income accruing to the owners of the (other) immobile resources (e.g., general partners in major New York law firms) would be state-invariant, given by the equal-sized triangles $A^{+} B w_{i j}^{+}$in the high-demand state and $A^{-} C w_{i j}^{-}$in the low-demand state. In this admittedly special case, all income risk is borne by workers of type $i$, and no income risk is borne by the owners of the other productive resources.

Now compare this with the polar opposite case where labor of type $i$ is costlessly mobile among regions. To keep the example simple, suppose that the high- and low-demand states shown in Figure 1 are equally probable, that the wage facing type- $i$ workers in the rest of the economy is non-stochastic and is given by $w_{i}$, and that $w_{i}=.5 w_{i j}^{+}+.5 w_{i j}^{-}$ is a simple average of the high and low wages shown in the figure. ${ }^{17}$ In this case, it is easily seen from the figure that type- $i$ workers would move into region $j$ in the high-

\footnotetext{
${ }^{15}$ These ideas have been developed more formally in Wildasin (2000).

${ }^{16}$ The following discussion draws on Wildasin (1995).

${ }^{17}$ None of these specific assumptions are essential; the key point is that demand for labor of a particular type is not perfectly correlated across all regions. If it were, there would be no incentive for labor to move among regions; since we are now exploring the implications of observed internal migration, situations where such migration would not occur are not of interest.
} 
demand state of the world, with employment increasing to $l_{i j}^{+}$; high demand, in this case, produces a quantity adjustment but no price adjustment. In the low-demand state, workers leave region $j$, with employment falling to $l_{i j}^{-}$. In both states, workers receive the same income as that prevailing elsewhere in the economy, namely, $w_{i}$. This is the same as the average or expected wage in the case where these workers are immobile. However, their income is now state-invariant whereas previously it varied with the state of the world. The owners of the immobile resources now receive income equal to $A^{+} F w_{i}$ in the high-demand state and $A^{-} D w_{i}$ in the low-demand state. Note that the expected income of the immobile factor owners is now higher, by the amount $D E C+B E F$, but their income, which previously was state-invariant, is now risky. In short, labor mobility in this example completely shifts the distribution of income risk from workers to owners of immobile resources, it leaves unchanged the average income of workers, and it raises the expected or average income of immobile resource owners.

Note that the high- and low-demand situations portrayed in Figure 1 can also illustrate a situation where there are differing demand conditions in two different regions. In one region, local industries using type- $i$ workers are flourishing, while in the other region, such workers are in low demand. The movement of these workers from one region to the other then gives rise to the efficiency gain represented by the two triangles $D E C$ and $B E F$. While one region thus attracts workers of one type, that same region may be in the opposite situation with respect to workers of other types - i.e., even as one or more local industries may be increasing their employment of workers with one type of skill (say, a particular type of legal services), others may be shedding workers with a different type of skill (say, a particular type of medical training). Such a region would exhibit a level of gross migration in excess of net migration; in fact, it, and other regions, might experience no net migration whatsoever even as workers of different types move from regions where their skills are in low demand to regions where the enjoy better employment opportunities. Note, however, that such gross migration is still efficiency-enhancing, even if it does not result in any net migration. For this reason, an analysis that treats all labor as homogeneous will underestimate the efficiency gains from labor mobility. Low levels of net migration would be estimated to yield little if any productivity gains, whereas the productivity gains from mobility could be very large if internal migration results in large but offsetting gross migration. This latter case seems to typify the US and Canadian labor markets.

This simple analysis shows that (a) there are efficiency gains from the free mobility of labor (aggregate expected or average income goes up), (b) free mobility tends to equalize real incomes within a given skill or occupational category across regions, (c) the distribution of these efficiency gains may accrue to resources other than mobile workers, and (d) free mobility of labor can alter the distribution of income risk among 
different factors of production. In the example illustrated in Figure 1, free mobility of labor reduces (in fact eliminates) the variability of earnings for type- $i$ workers without affecting expected earnings. It follows that acquisition of the specialized skills needed to become that type of worker is a more attractive investment for risk-averse workers, assuming, as is reasonable, that they are not able to insure their future earnings. In other words, the mobility of specialized labor influences not only the efficiency of utilization of a labor force with given skills, but the incentives to invest in the acquisition of specialized human capital in the first place. Persistently high levels of internal migration by highly-educated workers within the US and Canadian labor markets, with gross flows among regions going in opposite directions, suggest that local industries in these economies are subject to continuously changing conditions that result in shifting demands for workers in different occupational or skill categories. Highly-integrated markets providing relocation options over the life cycle affect both the expected lifecycle return on investment in specialized human capital and its riskiness, and thus the demand for higher education and other opportunities for skill acquisition.

\section{Higher Education in the US and Canada}

Riddell (2001) provides a useful survey of the educational systems of Canada, the US, and other OECD countries. ${ }^{18}$ As one might have anticipated, both Canada and the US stand out as countries with high levels of education, at least measured in terms of readily-quantifiable and comparable indicators. Of particular interest for the present discussion, expenditures on post-secondary education amount to about $2.5 \%$ of GDP in both countries (1995 data), as compared with the OECD average of $1.3 \%$. Of people aged 25-64, $19 \%$ of Canadians and $27 \%$ of US residents have completed university education, as compared with only $14 \%$ for OECD countries as a whole; Canada actually leads the OECD countries with over $25 \%$ having completed some form of post-secondary (including non-university) education.

In both the US and Canada, subnational governments, principally at the provincial and state levels, are heavily involved in the provision of higher education through public-sector higher education institutions. In both countries, the public sector is also involved in the financing of higher education, partly through direct and indirect subsidization of public institutions of higher education but also through direct and indirect subsidies to students (or to their families).

\footnotetext{
${ }^{18}$ See also Riddell and Sweetman (1999).
} 
Taking the US first, note from Figures 2, 3, and 4 that the four most important sources of finance for degree-granting institutions of postsecondary education in the US during the past two decades have been state governments, payments of tuition and fees by students, "sales and services," and revenues from the Federal government (see National Center for Education Statistics (2002) and Barbett and Korb (1999) for further discussion). As seen in Figure 2, the first two of these account for about half of all revenues, with funding from state governments declining from $30.7 \%$ of the total in 1980 to $23.1 \%$ by 1995 as tuition and fees rose from $21.0 \%$ to $27.9 \%$. (Both of these trends were monotonic.) "Sales and services" consistently account for approximately $20 \%$ of all revenues over this period; about half of this total represents revenue from university hospitals. The Federal government provided $14.9 \%$ of university revenue at the beginning of this period, a share that declined slightly to $12.1 \%$ by the end of the period. Figures 3 and 4 provide similar data for public and private institutions, respectively. The most noteworthy difference between the two is the role of state government financing, which declined from about $45 \%$ to about $35 \%$ of all revenues for public institutions during the period 1980-1996 while constituting a tiny share of the financing of private institutions. For public institutions, the (monotonically) falling share of state government funding was offset by a rising share of tuition and fees, which grew (monotonically) from $12.9 \%$ of revenues in 1980 to $19.0 \%$ in 1996 . For private institutions, tuition and fees also rose during this period, from $36.6 \%$ to $43.0 \%$; for these institutions, revenues from the Federal government fell by about 5 percentage points and revenues from sales and services fell by about 2 percentage points. ${ }^{19}$ The most important trend revealed by these figures is that direct public sector payments to colleges and universities, particularly expenditures by state governments, are dwindling in relative importance over time. In 1980, the Federal, state, and local governments together accounted for about $48 \%$ of the revenues of all higher-education institutions, whereas by 1995 this share had fallen to $38 \%$. In this respect, public sector involvement in the provision of higher education has fallen substantially.

The fact that tuition and fees are rising in importance relative to direct support for higher education institutions does not imply that public-sector financing for higher

\footnotetext{
${ }^{19}$ No short statement about the financing of higher education can do justice to its many complexities. As just one example: while tuition and fees were increasing on the "revenue" side, so were university "expenditures" for financial aid to students - though the latter less than fully offsets the former. Furthermore, while increases in endowment income or unrestricted gifts clearly increase the resources at the disposal of universities, it is not at all clear that the same can be said for grants, contracts, and restricted gifts. For example, a hypothetical $\$ 10$ million grant from the government to build a $\$ 12$ million cyclotron would require a $\$ 2$ million contribution from other university resources and might thus conceivably be viewed as a "net loss." How to draw the boundaries between revenues and expenditures and how to determine the "net income" from grants, contracts, hospital services, athletics, etc. are very difficult problems both at a conceptual and at a practical level.
} 
education in general is declining. For instance, the Federal and state governments provide grants and loans to students to defray the cost of higher education; these outlays account for a portion of tuition and fees. In addition, there are special provisions in the tax law, particularly at the Federal level, that allow for tax-sheltered saving for higher education. The not-for-profit status of colleges and universities allows them to avoid direct taxation, and they generally qualify as institutions that can receive taxdeductible contributions from individuals or businesses. Government subsidization of health care for the poor, elderly, or other groups assists medical schools and hospitals managed by higher-education institutions. Finally, and presumably not least, the taxation of earnings provides some special advantages for investment in human capital. Once education is completed, the government captures a portion of the return to education through taxes on earnings and consumption, thus reducing the net return to investment in education. Taxes also reduce the cost of investment in human capital, however, most notably because the cost of foregone earnings is expensed rather than depreciated, unlike the cost of investment in non-human capital. If earnings (or consumption) were taxed at a uniform rate at all points in the life cycle and if there were no other tax distortions in the economy, tax policy would be neutral in its impact on incentives to invest in human capital, and thus be more favorable than the tax treatment of investment in non-human capital (at least those investments in non-human capital that are not tax-sheltered or tax-favored in some other way). ${ }^{20}$ To this author's knowledge, no adequate measurements exist of of the full extent of all of these subsidies for higher education, some of which are highly implicit. It appears, however, that public-sector for higher education has been shifting away from direct support to public-sector institutions and toward support for individuals obtaining higher education, with Federal support, especially through the tax system, growing in importance relative to support from state governments.

In very general terms, public sector involvement in Canada exhibits many of the same features as the US. In 1999-2000, total university expenditures in Canada amounted to about $\$ 14.1$ bn. As shown in Table 8, the combined contributions of the Federal, provincial, and local governments accounted for more than half of all university revenues during the mid- to late-1990s, with provincial governments taking the lead role. A direct comparison with US data is quite problematic because of possible differences in accounting conventions and in the population of institutions included in the data; thus, for example, "Sales of services and products" amount to less than $10 \%$ of university revenues in Canada, but this may well reflect (as one of several possibilities)

\footnotetext{
${ }^{20}$ It should be noted, however, that to the extent that earnings are taxed at progressive rates over the life cycle, this tax preference for investment in human capital is offset or possibly more than offset. On the other hand, sales taxes and especially the payroll tax are important components of the overall tax structure which do not have progressive rate structures.
} 
differences in the accounting for revenues accruing to university-related health-care providers. For present purposes, it is of much greater interest to note that direct provincial government support for universities declined markedly in relative importance during the period 1994-1999, from $53.3 \%$ to $45.3 \%$ of revenues - bringing the total government share from $62.8 \%$ down to $55.0 \%$ in a brief period of time. Student fees rose from $16.0 \%$ to $19.3 \%$ of revenues during the same period, a large increase in proportionate terms though still well below the corresponding (if not fully comparable) figures for the US.

As in the US, the Canadian public sector contributes directly and indirectly to the financing of higher education in many ways other than through direct support for institutions of higher education. Publicly-financed loans and scholarships are available for students, tenable at private as well as public institutions; these institutions may be located in Canada but also may be foreign institutions. ${ }^{21}$ Federal and provincial tax systems alter the incentives to invest in human capital in ways similar to those described above for the US.

The key conclusions to draw from this brief description of education finance in the US and Canada are the following. First, in both countries, subnational governments have played a very important role in direct support to institutions of higher education. This role is declining over time, however, relative to other sources of financing. The change in the structure of financing is partly a change in the nature of the aid recipient - i.e., to an increasing extent, the student or the student's family rather than the higher-education institution - and partly a change in the level of government that is providing the explicit and implicit aid - i.e., a shift toward increased reliance on higher-level relative to lower-level governments.

\section{Labor Market Integration and Fiscal Competi- tion in North America}

The economies of Canada and the US are highly internally integrated; both have been characterized by very liberal internal trade conditions for a long period of time. As the discussion of Section 3 makes clear, labor markets in the US and Canada are also highly internally integrated, characterized, as they are, by persistent migration flows over large regions (provinces, states, Census regions). Both countries have highly educated labor forces, by world standards, and the level of educational attainment has

\footnotetext{
${ }^{21}$ For example, the Ontario Student Assistance Program (OSAP) provides assistance to students attending approved non-Canadian colleges and universities, such as the University of Kentucky.
} 
risen steadily over the course of the past century. Internal migration options seem to be particularly important for highly educated individuals. Capital markets are also highly integrated within these countries.

The economies of the US and Canada are also, to some degree, integrated with each other, and with respect to the rest of the world. There has long been a high volume of trade between these two economies, and recent policy initiatives - notable, NAFTA - strengthen the opportunities to continue and expand trade. The mobility of capital and labor between Canada and the US is also relatively high, and it is partly a matter of policy choice whether to increase or decrease the integration of labor and capital markets. Although flows of labor go in both directions across the US-Canada border, Canada has experienced negative net migration vis-a-vis the US, a fact that has led some, in Canadian policy debates, to express concern about a North-South "brain drain." Borjas' (1993) analysis indicates that Canada attracted migrants from the US during the 1970s and 1980s who tended to earn less than native Canadians whereas Canadians migrating to the US tend to enjoy higher earnings than US natives. It is of interest to note, however, that Borjas finds that migrants going in either direction tended to have higher amounts of education than destination-country natives - another indication, perhaps, of the heterogeneity of high-skilled workers. Several analysts have observed that the amount of North-South migration is now lower than was formerly the case; Helliwell (1999), for instance, notes that the number of Canadians residing in the US has been steadily falling over time. Finnie (2001) notes that the movement of highly-skilled workers from Canada to the US has been relatively modest, in some respects, and has also been concentrated in particular occupational groups (e.g., physicians), suggesting that policy responses to such mobility, if any, might best be targeted at particular sectors of the economy. Coulson and Devoretz (1993) find that immigrants to Canada have brought considerable amounts of human capital into the country, though immigration restrictions reduced human capital inflows substantially between about 1970 and the late 1980s. Of course, the original brain drain literature (e.g., Bhagwati and Partington (1976)) was concerned precisely with the fact that developed countries like the US and Canada were net recipients of human capital from less-developed countries. Both the US and Canada continue to be net immigration countries and attract both well- and poorly-educated migrants from the rest of the world.

Helliwell (1997, 1998) has argued convincingly that "borders matter" both for trade and for migration. The volume of interprovincial trade in Canada is very high relative to trade across the US-Canadian border. Furthermore, internal migration in each of these countries is much larger than migration between the two. There are many reasons why this may be the case; attachment to home, language, custom, and familiarity 
with social norms may all contribute to greater degrees of economic integration within countries than is found among them. One could conclude that competition for highlyskilled human resources should not be a policy priority for Canada or, for that matter, for the US. No doubt, fiscal, educational, or other policy reforms cannot be driven solely by competition for human resources without full consideration of other policy dimensions. Still, competition for human and other productive resources does exist and it is worth considering its implications. The following remarks attempt to pull together some ideas from the discussion in previous sections, focusing on the analysis of tax and expenditure policies, including higher-education finance, in an integrated market environment.

\subsection{Efficiency and Distributional Effects of Integration}

The potential benefits from trade in goods and services, both within and among countries, have been thoroughly discussed and do not require additional comment here. Aside from general gains from trade, benefits from greater product variety, economies of scale, or greater competition, of course, trade is also thought to affect factor prices and the distribution of income, as mentioned above. Trade is also thought to have contributed to widening inequality in the distribution of wages $^{22}$, as well as to increased riskiness of income: openness, it is argued, may expose an economy to more shocks from fluctuations in external markets. The effects of trade on the distribution and riskiness of income are important for fiscal policy because large fractions of government expenditure and major elements of the tax systems in both the US and Canada, as in all other high-income countries, serve to alter the distribution of income and of income risk. If trade contributes to greater earnings dispersion, then increased redistributive interventions by the public sector would be needed if the distribution of net income is not to become more unequal (see, e.g., Rodrik (1998), Agell (1999, 2000)).

As observed above, factor mobility can contribute to more efficient utilization of existing resource stocks. Persistent internal migration in the US and Canada has presumably given rise to significant efficiency gains in both economies. International mobility of labor and capital can likewise contribute to higher productivity. Factor mobility, like trade, also affects factor returns. In a classical two-factor production function $F(K, L)$ with output depending solely on capital and labor, factor prices are governed

\footnotetext{
${ }^{22}$ The extent to which this is actually the case had been a matter of intense study; Zhu and Trefler (2001) characterize the current state of professional opinion on this topic as a "20\% solution" according to which only about $20 \%$ of the recent increase in earnings inequality can be explained by trade.
} 
by the capital/labor ratio. In a more general setting with many factors of production, factor prices, as shown in (1), depend in less predictable ways on factor proportions because of potentially complex substitute/complement relationships. As noted in Section 3, the fact that gross labor flows far exceed net labor flows with the US and Canada provides evidence that different types of labor are not highly substitutable for one another. In fact, the high degree of mobility of highly-educated individuals indicates both that high- and low-skilled labor are imperfect substitutes and that different types of high-skilled labor are also imperfect substitutes. For this reason, it is difficult to predict the distributional impact of factor flows. It may be reasonable to suppose as a first approximation, however, that high-skilled labor, capital, low-skilled labor, and natural resources are generally complementary inputs. For any given type of labor, mobility reduces disparities in earnings (or, more precisely, real incomes) among regions. This is true within countries and among countries. If integration of labor markets leads to higher levels of investment in human capital, it can be expected to lead to higher returns for complementary inputs, including low-skilled labor.

Increased labor mobility between the US and Canada, and between North America and the rest of the world, can be mutually beneficial, in terms of allocative efficiency, for the same reason that internal migration in both countries contributes to more efficient resource utilization. Observed migration behavior suggests that the efficiency gains from mobility are particularly important for highly educated workers. The full generalequilibrium effects of greater factor-market integration for highly-skilled workers are complex, but, leaving aside for one moment the issue of education finance, greater opportunities to participate in "large" labor markets would generally be expected to enhance the lifetime earnings prospects for young people who invest in specialized skills by reducing their lifetime earnings risk. For both Canadian and US university students, the option to search for employment in locations beyond state, provincial, or national boundaries is valuable and contributes to the incentive to obtain higher education.

\subsection{Fiscal Competition: Education Finance and Tax Policy}

The fiscal systems of the US and Canada are extremely complex, and these complexities should be borne in mind when attempting to assess the fiscal implications of household mobility. In brief, complexities arise (a) because households interact with interact with fiscal systems over their entire life cycles, (b) they interact both with the expenditure and the revenue elements of fiscal systems, and (c) they interact simultaneously with the fiscal systems of national, state/provincial, and local governments. For example, many types of public expenditures - health, education, pensions - are 
directed either toward children or toward elderly people. The bulk of tax and nontax revenues are collected principally from people in the middle part of the life cycle. The distribution of the burdens of taxation and of the benefits of public services vary not only with age but with income, household size and composition, and many other attributes. This is true both for national and subnational governments. The lifetime distribution of the benefits and burdens of government on different types of people is only imperfectly understood. ${ }^{23}$

Migration changes the demographic composition of a region, and adds yet another dimension to the relationship between the individual and the public sector over the life cycle. A young person may benefit from education provided by local schools and by state or provincial governments and may then relocate either to other states/provinces or to another country. This creates a potentially serious problem for the financing of higher education, in particular. A jurisdiction that attempts to use high levels of taxation to finance high levels of education may find that the beneficiaries of education spending then migrate to other jurisdictions, reducing the tax base with which education spending is to be financed. Indeed, standard models of fiscal competition typically lead to the conclusion that a small, open jurisdiction would optimally impose a zero net fiscal burden on a freely-mobile resource.

The logic underlying this conclusion is easily illustrated using Figure 1. Suppose that labor of type $i$ earns an exogenously-fixed net return of $w_{i}$ on the external market, and that the demand for labor type $i$ in region $j$ is given by, say, $D_{i j}^{+}$. In the absence of any taxes or subsidies, the equilibrium level of employment in this region would be $l_{i j}^{+}$, assuming that labor is freely mobile. If this region imposes a tax of $B E$ on each unit of labor, then the equilibrium employment level would be only $l_{i j}$, as the gross wage for this type of labor rises to $w_{i j}^{+}$. Assuming that immobile resources in the region are owned by local residents, the loss in income to immobile resources, $w_{i j}^{+} B F w_{i}$, is greater than the tax revenue collected, $w_{i j}^{+} B E w_{i}$, and real income accruing to people in the region would fall by $B E F{ }^{24}$

Fundamentally, this result - which of course must be qualified when the underlying assumptions are altered - can be viewed simply as a variant of the standard optimal tariff argument. The same principles explain why it is also optimal for a small jurisdiction not to subsidize mobile resources. Note that these results obtain whether mobile resources flow into or out of a jurisdiction, and whether the magnitude of observed

\footnotetext{
${ }^{23}$ Research on "generational accounting" (see, e.g., Kotlikoff (1993), Auerbach et al. (1999)) highlights the importance of the life-cycle impact of both tax and expenditure policies. In general, trying to measure the distribution of the benefits of public services over the life cycle presents a larger measurement challenge than is true for taxes or for cash benefits such as public pensions.

${ }^{24}$ See, e.g., Cremer et al. 1996 and Wildasin (1998) for discussion and further references.
} 
flows is small or large, just as the standard optimal tariff argument applies equally to export taxes, and does not depend on the volume of trade.

Although these observations are analytically extremely obvious, they depart quite significantly from many common policy prescriptions. For instance, in the context of "brain drain" debates, the departure of highly-trained individuals from a jurisdiction is often viewed as self-evidently a bad outcome. One might then suppose that subsidies to retain highly-skilled individuals would be an appropriate policy response. In fact, however, a net subsidy to highly-skilled workers is not an optimal policy, unless one can show that there are positive externalities associated with the presence of such individuals. Note that this conclusion applies independently of the size of the local endowment of labor of type $i$ and, thus, independently of whether labor flows into or out of the region, whether in large or small amounts. That is, the policy conclusion follows independently of the observed level of in- or out-migration. The key question for determining the optimal policy is whether the jurisdiction is small or large relative to external markets, and whether it is open (or could be made open) to these markets. With reference to internal migration in the US and Canada, or to migration between these two countries, the crucial issue is not whether there is positive or negative net migration into or out of any one province, state, or country, but whether labor markets among regions are integrated or isolated. The high gross levels of internal migration within the US and Canada testify to the fact that labor markets within these countries are significantly linked. Migration between the US and Canada shows that there are linkages between the US and Canadian labor markets, though the degree of integration between the two is at least in part a matter of policy choice and could be enhanced or diminished by either or both countries, if desired.

The competition for mobile resources is often asserted to lead to a "race to the bottom," which is usually interpreted to mean, for instance, that competition leads to reductions in taxes. This is in fact not an accurate interpretation of the analysis. Many public services, especially those such as education, health, and others that relate to human resources, exhibit what is known as "congestibility," which is to say that their cost of provision depends partly on the size of the population being served. For instance, the total cost of providing education to 1,000 students is far less than the cost of providing education to 20,000 students - that is, the incremental or marginal cost of educating one more student is not zero. Indeed, it is commonplace to measure education costs in terms of cost per student - a crude but useful first approximation that implicitly assumes that marginal and average cost are equal. What does the theory of fiscal competition suggest should happen to fiscal systems when public services exhibit congestibility? It does not imply that taxes are driven toward zero, any more than perfect competition among firms implies that prices are driven toward 
zero. Rather, net fiscal burdens, the value of taxes paid by mobile resources net of the cost of providing them with public services, are driven toward zero. In particular, if the marginal cost of providing public services to those who use these services is high, then competition among jurisdictions should lead to high public-sector charges for those users. In the case of higher education, if students or their parents are relatively highly mobile, fiscal competition is expected to lead to greater reliance on student fees and charges or on other revenue instruments that similarly link revenues with costs. Fiscal competition would be expected to limit the extent of redistributive financing of higher education - that is, the financing of higher education in ways that allow some to utilize scarce educational resources that are paid for by others. The most obvious way in which this can occur is through increased reliance on tuition and fees assessed by higher-education institutions on currently-enrolled students.

Does this mean that higher education cannot or should not be financed with standard revenue instruments, such as income or consumption taxes, when skilled workers are mobile? Such a conclusion would be unwarranted, at least in an unqualified form, for at least three reasons.

First, if taxes are not used to finance higher education, what is the alternative? If students have or can obtain sufficient financial resources to pay the full cost of their own education, then indeed the case for tax financing of higher education is substantially weakened. It might still be argued that higher education provides spillover benefits to the rest of society and that it therefore warrants public-sector support. But, as estimates of the education premium confirm, a very substantial part of the benefit of investment in higher education accrues to students in the form of higher earnings. If they are the principal beneficiaries of their own education, and if they enjoy relatively high lifetime incomes, there is little normative justification for the subsidization of higher education. This supposes, however, that students can, if necessary, borrow the money needed to finance their education. If they are credit-constrained, the level of investment in higher education would be inefficiently low. The high level of publicsector expenditure in support of higher education that has developed in Canada and the US during the past century was undoubtedly predicated, at least in part, on the assumption that private capital markets would not provide sufficient resources for education. In the presence of such a capital market failure, reliance on public-sector revenue sources, even ones which give rise to allocative distortions, may be part of an optimal policy. In effect, the government's revenue system offsets the misallocation that would otherwise result from a "missing market;" the young who benefit from the provision of publicly-supported education in effect repay an implicit loan from the government through their payment of taxes later in life. ${ }^{25}$

\footnotetext{
${ }^{25}$ In practice, earnings are not taxed at a uniform rate over the life cycle, partly due to progressivity
} 
Second, even if young and well-educated people are highly mobile, the same is not necessarily true for older people, including the parents of children who are utilizing publicly-supported higher-education systems. Although students certainly benefit from being educated, so do their parents, if they are altruistic toward their children. One can visualize a traditional US or Canadian public university as an institution through which parents, through their payment of income and other taxes, purchase higher education for their children. Parents may be relatively immobile and thus relatively unresponsive, along the migration margin, to local taxes. Furthermore, if access to publicly-supported higher education is contingent on residence within a state or province (meaning, traditionally, the residence of a student's parents), then the net fiscal burden imposed on parents by publicly-supported higher education may be rather modest: the burden of taxes is offset by the benefit of education for one's children. In terms of Figure 1, a "tax" of $B E$ is properly interpreted not just as a tax in the strict sense, but as a net fiscal burden, i.e., as the burden of location-contingent taxes net of the location-contingent benefits of public services to the individual. To the extent that the benefits of higher education (or other public services) offset the taxes paid by residents, the size of the "wedge" in the diagram is reduced.

Third, as noted above, the degree of mobility of labor within the US and Canada is greater than the degree of international mobility. Perhaps the competition for highlyskilled individuals by states or provinces means that these units of government will (or, from the perspective of their local constituencies, should) alter their revenue systems in ways that reduce the net fiscal burdens falling on those with high earnings. If these individuals are not particularly mobile internationally, then they can be taxed more heavily by national governments. The revenues accruing to the national governments could then be used, if desired, to support higher education. This support could be directed to public higher-education institutions through direct grants, or through grants to state and provincial governments on condition that the resources are used to support public universities. It could also be directed to students through national student loan or scholarship programs, or to their families, through tax-preferred savings vehicles, with students then able to use these public-sector resources to defray the cost of their higher education at whatever institutions, public or private, they might

of rate structures and partly because of ongoing tax reforms. Progressivity of the rate structure, by itself, tends to discourage investment in human capital, since education raises lifetime variability of earnings by steepening the life-cycle earnings profile. As observed by Sturn and Wolhfahrt (2000), however, the "condensing" of earnings over the life cycle means that progressive taxation shifts tax burdens toward more-educated members of the population, thus recouping some of the subsidies to education received earlier in the life cycle. They argue that progressive tax systems thereby recoup significant portions of the subsidies to education that are made available in early stages of the life cycle, meaning that publicly-supported higher education, in the presence of progressive tax systems, has smaller redistributive impacts than might otherwise appear to be the case. 
attend. Indeed, financial support of this latter type is found both in the US and Canada. In other words, interprovincial or interstate fiscal competition could lead to an upward-reassignment of public-sector responsibility for higher-education finance that is, to a restructuring of public-sector financing roles among levels of government within a country.

While one should not exaggerate the importance of the competition for human resources for the structuring of education finance and for revenue systems, gradual changes in the degree of economic integration within North America as well as with respect to the rest of the world may create pressures for policy change. Compared to the period immediately after World War II, which saw a large expansion of the public-sector role in higher education, the opportunities for purely private financing of higher education have certainly increased. Economic growth has led to increases in wealth that leave many families much better equipped to pay for higher education for their children. Financial institutions provide much better opportunities for many students to borrow the resources necessary to finance their education, especially with support from national (and sometimes subnational) governments in the form of loan guarantees or other incentives, and, as noted above, a variety of tax preferences and savings incentives help families to accumulate resources with which to finance higher education for their. These developments presumably reduce the importance of keeping tuition and fees at low levels.

Of course, the observed trends in higher-education finance also reflect underlying demand and supply conditions. The private return to human capital investment - often measured by the "education premium," that is, the higher earnings enjoyed by bettereducated workers - affects the incentive for young people to pursue higher education and thus the market environment within which higher-education institutions operate. Freeman and Needles (1993) find that the education premium has risen markedly in US and, to a lesser extent, in Canada, during the 1980s. The ratio of college- to highschool-educated fell somewhat in US, a "lagged response to decline in enrollments induced by falling return to college of the 1970s," while rising in Canada. According to Riddell and Sweetman (1999, p. 28), referring to the Canadian experience of the past decade, "[d] espite the substantial growth in the number of well-educated workers, and the decline in the supply of those with low levels of education, the relative earnings of university and college graduates did not fall relative to the less well-educated groups. [] We interpret this evidence to suggest that the demand for more educated workers has increased substantially over this period, sufficiently to absorb the large increase in their supply..." ${ }^{26}$ In such an environment, it is not surprising, perhaps, to see increases in tuition and fees for higher education. This is true independently of

\footnotetext{
${ }^{26}$ For further discussion of Canadian and US labor markets, see Riddell (1999).
} 
any pressures arising from fiscal competition among provinces or states.

Changes in the demand for and supply of highly-skilled workers in the US and Canada also affect earnings differentials between the US and Canada, as well as with respect to the rest of the world. Cet. par., rising in equality in the US relative to Canada would strengthen the incentives for highly-skilled Canadians to move to the US. What of the international competition for human resources?

The brain drain debate often tends to view international migration as a zero-sum phenomenon, and, without doubt, net migration flows are potentially important. As has been emphasized above, however, migration can be productivity-enhancing. The fact that higher education offers opportunities for employment on an international scale certainly increases the demand for higher education, even for countries that are net importers of highly-skilled workers. It is also worth noting that gross international migration flows are larger than net flows, though to a degree that is not easily measured. In general, resource flows international boundaries suggest gains from trade. Furthermore, the possibility of return migration should not be underestimated. A series of recent studies on Irish migration by Barrett (2002), Barrett et al. (2000), and Barrett and O'Connell (2001) show that Ireland, traditionally a country that lost many workers to emigration, including well-educated ones, has recently experienced substantial return migration, especially of high-skilled workers. These workers have enjoyed substantial gains in earnings relative to those who have stayed in Ireland, suggesting that migration has been productivity-enhancing for those who move. ${ }^{27}$ Furthermore, their return to Ireland appears to have reduced the earnings premium enjoyed by highskilled workers there. In the Irish case, at least, return migration has meant that the amount of permanent international migration has turned out to be smaller than the amount of temporary migration. Similar migration patterns across the Canada-US border, as indeed is observed across state and provincial boundaries within the US and Canada, can easily be imagined. Policy changes that liberalize migration across international borders presumably give rise to "gains from trade" even as they may increase the competitive pressures on national and subnational fiscal systems.

Although it is an issue with ramifications that go well beyond the "brain drain" debate, the tax treatment of highly-skilled individuals is often discussed in this context. More definitive analysis must await further investigation, but there is no doubt that the tax treatment of high-income individuals provides potentially fertile ground for intergovernmental competition because these individuals have such a large impact on

\footnotetext{
${ }^{27}$ This contrasts with the findings reported by Finnie (2001b) which show that internal migrants in Canada - especially young males - generally benefit from increased earnings, but that interprovincial return migration in Canada may actually be associated with earnings losses. These studies are not directly comparable in detail, however, and are not necessarily inconsistent.
} 
government revenues. By way of illustration, in 1999, the top $1.9 \%$ of taxpayers received $24.4 \%$ of income ${ }^{28}$; the top $0.16 \%$ of taxpayers received $11.2 \%$ of income. These figures testify to the degree of concentration of income in the US. The distribution of taxes is even more concentrated: the top $1.9 \%$ of taxpayers paid $43.4 \%$ of all personal income taxes (the major revenue source for the Federal government, along with the payroll tax for social security), and the top $0.16 \%$ of taxpayers paid $20.8 \%$ of these taxes. These very rich taxpayers paid an average income tax of almost $\$ 900,000$. The jurisdiction that succeeds in attracting such taxpayers is sure to enjoy a vast fiscal benefit. As a simple back-of-the envelope calculation, if half of the top $0.16 \%$ of taxpayers in the US in 1999 (about 100,000 taxpayers) had located in, say, Monaco, the US would have lost about $10 \%$ of all personal income tax revenues - about $\$ 90$ billion, much more than the entire proceeds of the estate tax and equal to about half of all corporation income tax revenue. These figures are very rough but demonstrate clearly that the locational choices of high-income individuals are a matter of importance, in terms of fiscal policy, far out of proportion to the numbers of such people, and it is therefore not unreasonable to argue that governments at all levels (both national and subnational) either will or should adapt their fiscal systems (or other policies) in ways that attract high-income individuals. ${ }^{29}$

These competitive pressures exist both at the international and subnational levels. Insofar as households are more mobile within countries, fiscal competition may be "more intense" for subnational governments. One might accordingly expect to see "upward reassignment" of redistributive policies, with national governments playing an increased role in providing financial support for students of modest means in search of higher education, accompanied by reductions in the amount of financial aid offered by subnational governments. ${ }^{30}$ The trends in higher-education finance described in Section 4 might be offered, tentatively, as evidence of this sort of policy change.

\footnotetext{
${ }^{28}$ Specifically, "adjusted gross income," or AGI, which is related but certainly not identical to true economic income. These figures are drawn from the US Treasury's Statistics of Income.

${ }^{29}$ It should perhaps be emphasized in this context that the key issue concerns the location, for tax purposes, of the incomes of the rich, which may or may not be where they spend 180 or so days per year. Discussion of fiscal competition in all of its aspects, including not only the tax treatment of high-income individuals but of corporations, and of expenditure policies that benefit different types of households and business activity, goes beyond the scope of the present paper, however. For further discussion and references, see Wildasin (2002).

${ }^{30}$ Determining the "degree of competition" for mobile resources is a difficult task, both conceptually and empirically. In this writer's view, explicit dynamic modeling of factor reallocations may provide the most fruitful avenue of approach to this issue (see Wildasin (forthcoming)). Decressin and Fatas (1995) provide an interesting empirical comparison of the "degree of labor mobility" between the US and Europe, focusing on the speed of labor-market adjustment to changing demand conditions.
} 


\subsection{Scope for Additional Research}

The foregoing discussion has touched on a large number of inter-related issues, including trade in goods and services within and among countries and its implications for factor markets and incomes; internal migration within the US and Canada and its implications for efficient resource allocation, the distribution of income, and income risk; the incentives to invest in higher education and the financing of higher education by national and subnational governments as well as by private individuals; the possible effects of fiscal competition on the financing of higher education and on the allocation of human resources among regions, both within and among countries. Many theoretical and empirical studies have contributed to a better understanding of these issues, but very substantial gaps remain.

The preceding discussion has identified several of these. Further analysis of the allocative and distributional effects of migration with heterogeneous workers would improve our understanding of the role of integrated labor markets. A fully satisfactory analysis cannot limit attention purely to the effects of migration on labor markets, but should also consider the impact of labor market integration on the allocation of and return to other factors of production, notably capital and natural resources. The implications of labor mobility for human capital investment are far from well understood. The interaction of labor markets with fiscal systems, including both tax systems and systems of higher education finance, should be investigated more fully in light of a more complete understanding of the role of internal and international labor mobility. Progress in these areas would contribute substantially to a better foundation for the analysis of the very complex policy issues that both Canada and the US must address as economic integration proceeds. 


\section{REFERENCES}

Agell, J. (1999), "On the Benefits From Rigid Labour Markets: Norms, Markets Failures, and Social Insurance", Economic Journal 109, 143-164.

Agell, J. (2000), "On the Determinants of Labor Market Institutions: Rent-Sharing vs. Social Insurance", unpublished.

Akbar, S. and D. J. Devoretz (1993), "Canada's Demand for Third World Highly Trained Immigrants: 1876-1986", World Development 21, 177-187.

Auerbach, A. J., L.J. Kotlikoff, and W. Leibfritz, eds. (1999) Generational Accounting Around the World (Chicago: University of Chicago Press).

Barbett, S. and R. A. Korb (1999), "Current Funds Revenues and Expenditures of Degree-Granting Institutions: Fiscal Year 1996" (Washington: National Center for Education Statistics).

Barrett, A. (2002), "Return Migration of Highly-Skilled Irish into Ireland and Their Impact on GNP and Earnings Inequality", in OECD (2002), 151-157.

Barrett, A., J. Fitzgerald, and B. Nolan (2000), "Earnings Inequality, Returns to Education and Immigration into Ireland", IZA Discussion Paper No. 167.

Barrett, A. and P. J. O'Connell (2001), "Is There a Wage Premium for Returning Irish Migrants?", Economic and Social Review 32, 1-21.

Bauer, T. and K.F. Zimmermann (1999), "Causes of International Migration: A Survey," in C. Gorter, P. Nijkamp, and J. Poot (eds.), Crossing Borders: Regional and Urban Perspectives on International Migration (Aldershot: Ashgate Publishing Ltd.), 95-127.

Bhagwati, H. N. and M. Partington (1976), Taxing the Brain Drain I: A Proposal (Amsterdam: North-Holland).

Borjas, G. J. (1993), "Immigration Policy, National Origin, and Immigrant Skills: A Comparison of Canada and the United States", in D. Card and R. B. Freeman (eds.), Small Differences That Matter (Chicago: University of Chicago Press), 21-44.

Bound, J. J. Groen, G. Kezki, and S. Turner (2001), "Trade in University Training: Cross-State Variation in the Production and Use of College-Educated Labor", NBER WP 8555.

Cremer, H., V. Fourgeaud, M. Leite-Monteiro, M. Marchand, and P. Pestieau (1996) "Mobility and Redistribution: A Survey," Public Finance 51, 325-352.

Coulson, B. G. and D. J. Devoretz (1993), "Human Capital Content of Canadian Immigrants: 1967-1987," Canadian Public Policy 29, 357-366.

Decressin, J. and A. Fatás (1995), "Regional Labor Market Dynamics in Europe," 
European Economic Review 39, 1627-1655.

Edmonston, B. (2002), "Interprovincial Migration of Canadian Immigrants," Vancouver Centre of Excellence, Research on Immigration and Integration in the Metropolis Working Paper No. 02-10.

Ehrenberg, R.G. and R.S. Smith (1988), Modern Labor Economics: Theory and Public Policy, 3rd. ed. (Glenview, Illinois: Scott Foresman).

Finnie, R. (2001) "The Effects of Inter-Provincial Mobility on Individuals' Earnings: Panel Model Estimates for Canada", Statistics Canada No. 163.

Freeman, R. B. and K. Needels (1993), "Skill Differentials in Canada in an Era of Rising Labor Market Inequality", in D. Card and R. B. Freeman (eds.), Small Differences That Matter (Chicago: University of Chicago Press), 45-68.

Hamilton, B. and J. Whalley (1984), "Efficiency and Distributional Implications of Global Restrictions on Labour Mobility: Calculations and Policy Implications", Journal of Development Economics 14, 61-75.

Hatton, T.J. and J.G. Williamson (1994), "International migration 1850-1939; An economic survey," in T.J. Hatton and J.G. Williamson (eds.), Migration and the International Labor Market 1850-1939, Routledge, London, 1994, 3-54.

Helliwell, J. F. (1997), "National Borders, Trade, and Migration," NBER WP 6027.

Helliwell, J. F. (1998), How Much Do National Borders Matter? (Washington: Brookings Institution Press).

Helliwell, J. F. (1999), "Checking the Brain Drain: Evidence and Implications," unpublished.

Kodrzycki, Y. K. (2001), "Migration of Recent College Graduates: Evidence from the National Longitudinal Survey of Youth", New England Economic Review.

Kotlikoff, L. (1993) Generational Accounting (New York: Free Press).

Krugman, P. (1991) Geography and Trade (Cambridge: MIT Press).

Melvin, J. R. (1985) "The Regional Economic Consequences of Tariffs and Domestic Transportation Costs", Canadian Journal of Economics 18, 237-257.

Mirrlees, J. A. (1971), "An Exploration in the Theory of Optimum Income Taxation" Review of Economic Studies 38, 175-208.

Mundell, R. A. (1957), "International Trade and Factor Mobility", American Economic Review 47, 321-335.

National Center for Education Statistics (2002), Digest of Education Statistics, 2001 (Washington: NCES).

OECD (2002), International Mobility of the Highly-Skilled (Paris: OECD). 
Riddell, W. C. (1999), "Canadian Labour Market Performance in International Perspective" Canadian Journal of Economics 32, 1097.

Riddell, W. C. (2001) "Education and Skills: An Assessment of Recent Canadian Experience", in P. Grady and A. Sharpe (eds.), The State of Economics in Canada: Festschrift in Honour of David Slater (Montreal and Kingston: McGill-Queen's University Press) 485-517.

Riddell, W. C. and A. Sweetman (1999), "Human Capital Formation in a Period of Rapid Change," unpublished.

Rodrik, D. (1998), "Why Do More Open Economies Have Bigger Governments?" Journal of Political Economy 106, 997-1032.

Smith, A. (1776), The Wealth of Nations (Modern Library).

Solow, R. M. (1963), Capital Theory and the Rate of Return (Chicago: Rand-McNally).

Stigler, G.J.(1951), "The Division of Labor Is Limited by the Extent of the Market," Journal of Political Economy 59, .

Sturn, R. and G. Wohlfahrt (2000) "Who Pays for Higher Education? A Note on the Neglected Role of Income Tax Progression," Finanzarchiv $5 \%$.

Topel, R.H. (1986) "Local Labor Markets." Journal of Political Economy 94, Part 2, 111-143.

Topel, R.H. (1991), "Specific Capital, Mobility, and Wages: Wages Rise with Job Seniority," Journal of Political Economy 99, 145-176.

Trefler, D. (1993), "International Factor Price Differences: Leontief Was Right!," Journal of Political Economy 101, 961-987.

Wildasin, D.E.,(1995), "Factor Mobility, Risk, and Redistribution in the Welfare State," Scandinavian Journal of Economics 97, 527-546. (An expanded version appears as "Factor Mobility, Risk, Inequality, and Redistribution," in D. Pines, E. Sadka, and I. Zilcha (eds.), Topics in Public Economics (Cambridge: Cambridge University Press, 1997), 314-339.)

Wildasin, D.E. (1998), "Factor Mobility and Redistributive Policy: Local and International Perspectives," in P. B. Sorensen (ed.) Public Finance in a Changing World (London: MacMillan Press, Ltd.), 151-192.

Wildasin, D. E. (2000), "Labor Market Integration, Investment in Risky Human Capital, and Fiscal Competition," American Economic Review 90, 73-95.

Wildasin, D. E. (2002), "Tax Coordination: The Importance of Institutions", Swedish Economic Policy Review 9(1), Spring, 2002, 171-194.

Wildasin, D. E. (forthcoming), "Fiscal Competition in Space and Time", Journal of Public Economics. 
Wildasin, D.E. and J. D. Wilson (1996), "Imperfect Mobility and Local Government Behavior in an Overlapping-Generations Model," Journal of Public Economics 60, 177-198. 


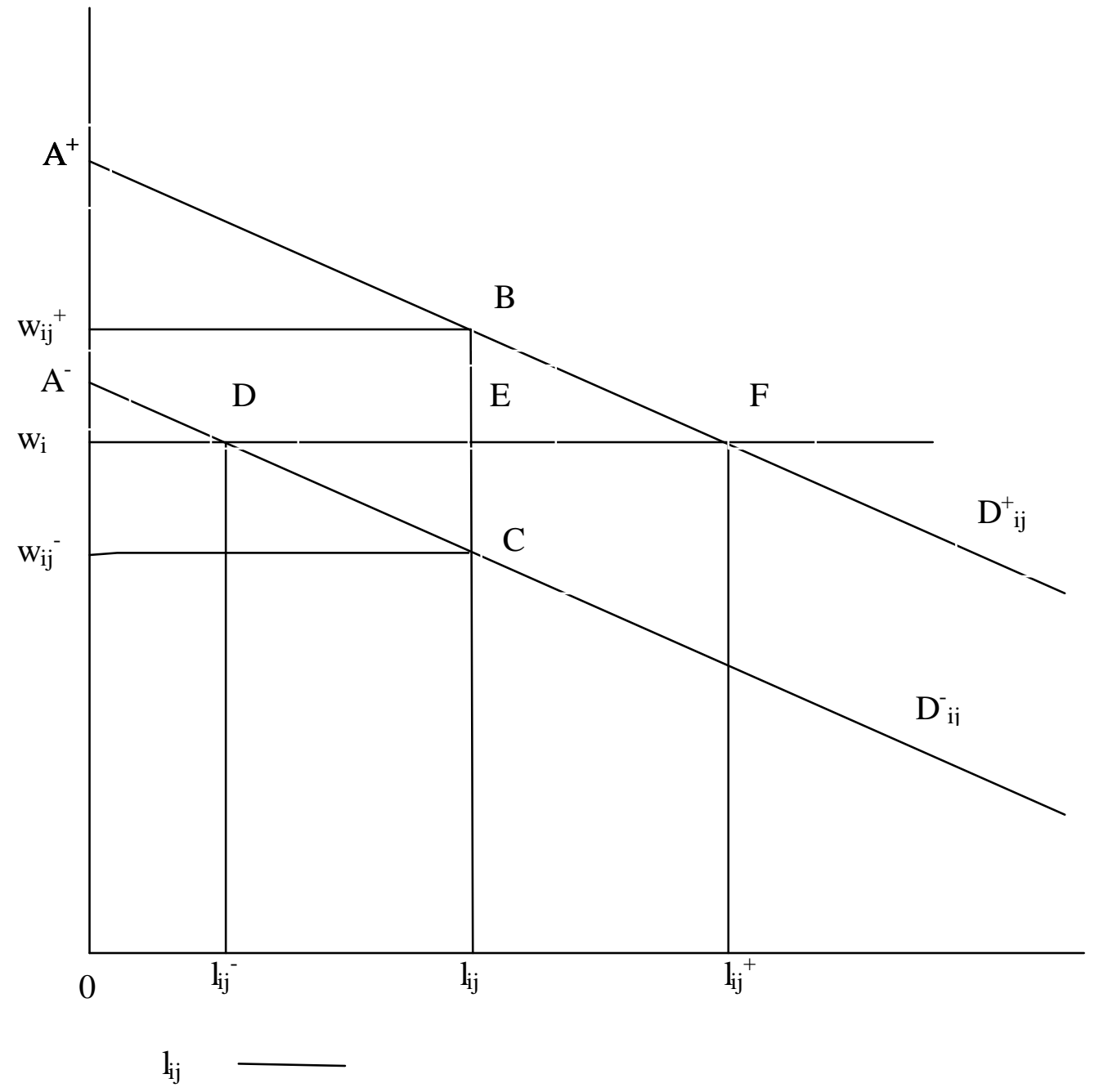

FIGURE 1 


\section{Figure 2: Revenue of US Degree-Granting Institutions, by Source, 1980--95}

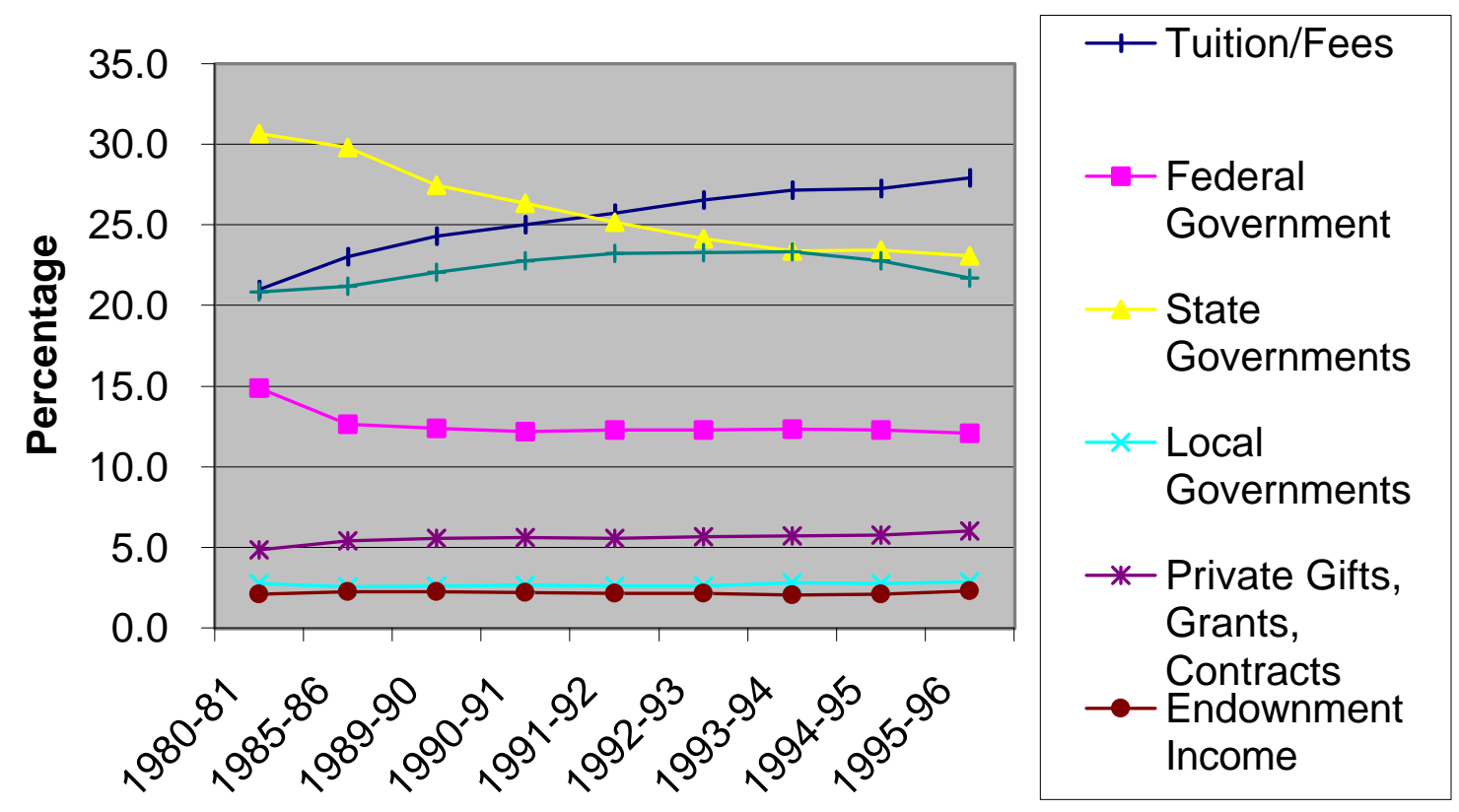

Year 


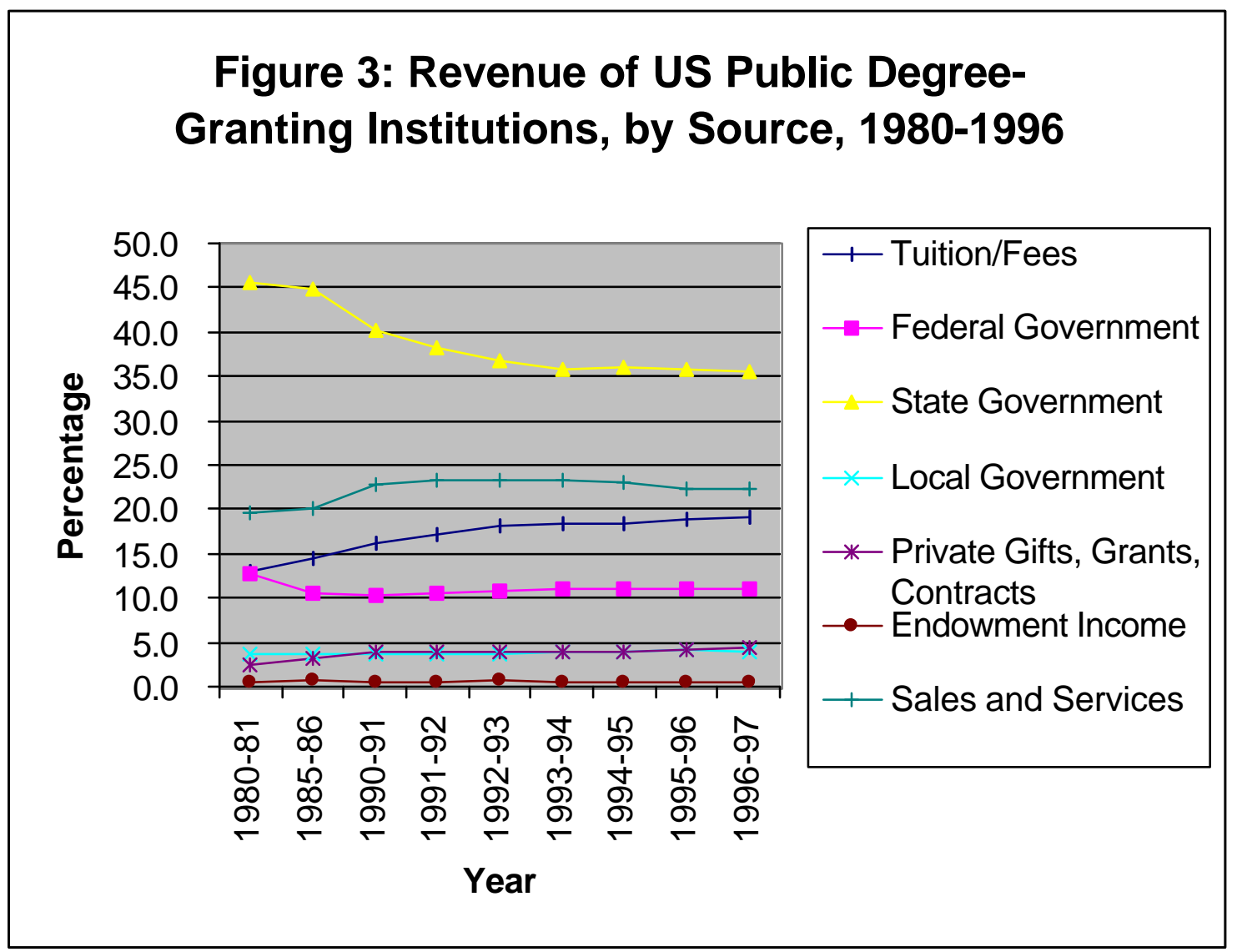




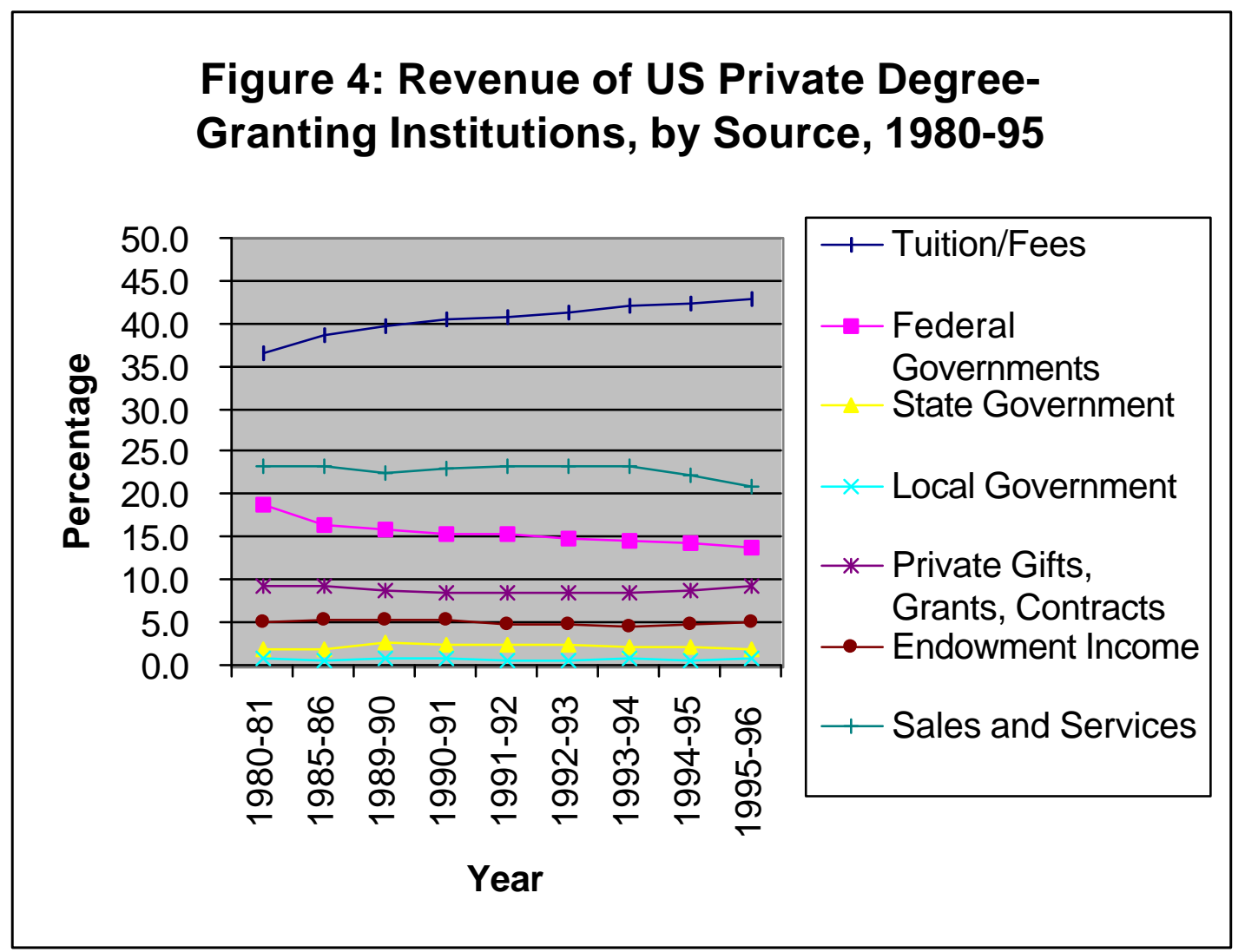




\section{TABLE 1}

\section{Population 5 Years and Over, Showing Mobility Status}

(Number, Place of Residence 5 Years Ago)

For Canada, Provinces, and Territories, 1991 and 1996

\begin{tabular}{|c|c|c|c|c|c|c|c|c|}
\hline 1991 & & & & & & & & \\
\hline & Canada & Newfdld. & PEI & $\begin{array}{l}\text { Nova } \\
\text { Scotia }\end{array}$ & $\begin{array}{c}\text { New } \\
\text { Brunswick }\end{array}$ & Quebec & Ontario & Manitoba \\
\hline Total & $24,927,870$ & 524,845 & 117,490 & 823,850 & 664,585 & $6,319,430$ & $9,225,700$ & 984,125 \\
\hline Non-movers & $13,290,690$ & 375,885 & 76,915 & 510,660 & 436,200 & $3,564,470$ & $4,797,795$ & 557,525 \\
\hline Movers & $11,637,180$ & 148,955 & 40,570 & 313,190 & 228,385 & $2,754,960$ & $4,427,905$ & 426,595 \\
\hline $\begin{array}{c}\text { Non- } \\
\text { migrants }\end{array}$ & $5,776,215$ & 76,565 & 17,770 & 165,140 & 120,000 & $1,382,255$ & $2,098,400$ & 275,780 \\
\hline Migrants & $5,860,970$ & 72,390 & 22,805 & 148,050 & 108,385 & $1,372,710$ & $2,329,505$ & 150,815 \\
\hline $\begin{array}{l}\text { Internal } \\
\text { migrants }\end{array}$ & $4,947,645$ & 69,710 & 21,825 & 139,410 & 102,990 & $1,230,860$ & $1,831,825$ & 126,305 \\
\hline $\begin{array}{l}\text { Intraprov } \\
\text { incial } \\
\text { migrants }\end{array}$ & $3,970,595$ & 48,975 & 13,035 & 86,150 & 67,155 & $1,148,865$ & $1,561,840$ & 82,255 \\
\hline \begin{tabular}{l}
\multicolumn{1}{c|}{ Interprov } \\
incial \\
migrants
\end{tabular} & 977,050 & 20,735 & 8,785 & 53,260 & 35,825 & 81,995 & 269,985 & 44,050 \\
\hline $\begin{array}{l}\text { External } \\
\text { migrants }\end{array}$ & 913,320 & 2,680 & 980 & 8,640 & 5,400 & 141,845 & 497,675 & 24,510 \\
\hline 1996 & & & & & & & & \\
\hline Total & $26,604,135$ & 516,455 & 123,790 & 843,750 & 685,045 & $6,588,580$ & $9,904,595$ & $1,019,590$ \\
\hline Non-movers & $15,079,410$ & 378,840 & 84,150 & 539,825 & 461,660 & $3,962,295$ & $5,635,420$ & 612,580 \\
\hline Movers & $11,524,725$ & 137,615 & 39,640 & 303,925 & 223,385 & $2,626,285$ & $4,269,180$ & 407,010 \\
\hline $\begin{array}{c}\begin{array}{c}\text { Non- } \\
\text { migrants }\end{array} \\
\end{array}$ & $6,130,740$ & 75,370 & 20,355 & 178,680 & 125,735 & $1,407,750$ & $2,252,460$ & 265,965 \\
\hline Migrants & $5,393,985$ & 62,240 & 19,285 & 125,245 & 97,650 & $1,218,535$ & $2,016,725$ & 141,050 \\
\hline $\begin{array}{l}\text { Internal } \\
\text { migrants }\end{array}$ & $4,465,295$ & 59,560 & 18,595 & 115,810 & 92,215 & $1,078,625$ & $1,561,110$ & 121,565 \\
\hline $\begin{array}{l}\text { Intraprov } \\
\text { incial } \\
\text { migrants }\end{array}$ & $3,575,025$ & 43,335 & 9,650 & 68,355 & 58,155 & $1,009,725$ & $1,367,090$ & 78,350 \\
\hline $\begin{array}{l}\text { Interprov } \\
\text { incial } \\
\text { migrants }\end{array}$ & 890,270 & 16,225 & 8,945 & 47,455 & 34,060 & 68,895 & 194,020 & 43,215 \\
\hline $\begin{array}{l}\text { External } \\
\text { migrants }\end{array}$ & 928,690 & 2,680 & 690 & 9,435 & 5,435 & 139,910 & 455,615 & 19,48 \\
\hline
\end{tabular}

\section{Source: Statistics Canada, 1996 Census Nation tables}




\section{TABLE 1 (cont.)}

\section{Population 5 Years and Over, Showing Mobility Status}

(Number, Place of Residence 5 Years Ago)

For Canada, Provinces, and Territories, 1991 and 1996

\begin{tabular}{|c|c|c|c|c|c|}
\hline 1991 & & & & & \\
\hline & Sask. & Alberta & $\begin{array}{c}\text { British } \\
\text { Columbia }\end{array}$ & Yukon & NW Terr. \\
\hline Total & 891,255 & $2,291,065$ & $3,011,330$ & 24,785 & 49,400 \\
\hline Non-movers & 544,015 & $1,081,105$ & $1,320,285$ & 8,775 & 17,045 \\
\hline Movers & 347,240 & $1,209,965$ & $1,691,050$ & 16,010 & 32,355 \\
\hline $\begin{array}{c}\text { Non- } \\
\text { migrants }\end{array}$ & 189,410 & 668,220 & 757,890 & 7,295 & 17,500 \\
\hline Migrants & 157,830 & 541,745 & 933,160 & 8,715 & 14,855 \\
\hline $\begin{array}{l}\text { Internal } \\
\text { migrants }\end{array}$ & 149,235 & 466,860 & 786,125 & 8,270 & 14,235 \\
\hline $\begin{array}{l}\text { Intraprov } \\
\text { incial } \\
\text { migrants } \\
\end{array}$ & 111,015 & 296,840 & 547,945 & 1,810 & 4,695 \\
\hline $\begin{array}{l}\quad \text { Interprov } \\
\text { incial } \\
\text { migrants }\end{array}$ & 38,220 & 170,015 & 238,175 & 6,460 & 9,540 \\
\hline $\begin{array}{l}\text { External } \\
\text { migrants }\end{array}$ & 8,595 & 74,890 & 147,035 & 440 & 620 \\
\hline 1996 & & & & & \\
\hline Total & 906,355 & $2,474,850$ & $3,456,245$ & 28,310 & 56,560 \\
\hline Non-movers & 556,695 & $1,244,925$ & $1,570,900$ & 11,805 & 20,320 \\
\hline Movers & 349,660 & $1,229,925$ & $1,885,345$ & 16,505 & 36,240 \\
\hline $\begin{array}{c}\text { Non- } \\
\text { migrants }\end{array}$ & 191,375 & 705,835 & 877,170 & 8,330 & 21,715 \\
\hline Migrants & 158,285 & 524,090 & $1,008,170$ & 8,170 & 14,530 \\
\hline $\begin{array}{l}\text { Internal } \\
\text { migrants }\end{array}$ & 148,580 & 453,845 & 793,650 & ,795 & 13,945 \\
\hline $\begin{array}{l}\text { Intraprov } \\
\text { incial } \\
\text { migrants }\end{array}$ & 101,055 & 291,200 & 541,025 & 1,840 & 5,230 \\
\hline $\begin{array}{l}\text { Interprov } \\
\text { incial } \\
\text { migrants }\end{array}$ & 47,520 & 162,645 & 252,625 & 5,955 & 8,710 \\
\hline $\begin{array}{l}\text { External } \\
\text { migrants }\end{array}$ & 9,710 & 70,250 & 214,520 & 375 & 590 \\
\hline
\end{tabular}




\section{TABLE 2}

\section{Population 5 Years and Over, Showing Mobility Status}

(Percentage, Place of Residence 5 Years Ago)

For Canada, Provinces, and Territories, 1991 and 1996

\begin{tabular}{|c|c|c|c|c|c|c|c|c|}
\hline & Canada & Newfdld. & PEI & $\begin{array}{l}\text { Nova } \\
\text { Scotia }\end{array}$ & $\begin{array}{c}\text { New } \\
\text { Brunswick }\end{array}$ & Quebec & Ontario & Manitoba \\
\hline \multicolumn{9}{|c|}{1991} \\
\hline Total & $100 \%$ & $100 \%$ & $100 \%$ & $100 \%$ & $100 \%$ & $100 \%$ & $100 \%$ & $100 \%$ \\
\hline Non-movers & $53 \%$ & $72 \%$ & $65 \%$ & $62 \%$ & $66 \%$ & $56 \%$ & $52 \%$ & $57 \%$ \\
\hline Movers & $47 \%$ & $28 \%$ & $35 \%$ & $38 \%$ & $34 \%$ & $44 \%$ & $48 \%$ & $43 \%$ \\
\hline $\begin{array}{l}\text { Non- } \\
\text { migrants }\end{array}$ & $23 \%$ & $15 \%$ & $15 \%$ & $20 \%$ & $18 \%$ & $22 \%$ & $23 \%$ & $28 \%$ \\
\hline Migrants & $24 \%$ & $14 \%$ & $19 \%$ & $18 \%$ & $16 \%$ & $22 \%$ & $25 \%$ & $15 \%$ \\
\hline $\begin{array}{l}\text { Internal } \\
\text { migrants }\end{array}$ & $20 \%$ & $13 \%$ & $19 \%$ & $17 \%$ & $15 \%$ & $19 \%$ & $20 \%$ & $13 \%$ \\
\hline $\begin{array}{l}\text { Intraprovi } \\
\text { ncial } \\
\text { migrants }\end{array}$ & $16 \%$ & $9 \%$ & $11 \%$ & $10 \%$ & $10 \%$ & $18 \%$ & $17 \%$ & $8 \%$ \\
\hline $\begin{array}{l}\text { Interprovi } \\
\text { ncial } \\
\text { migrants }\end{array}$ & $4 \%$ & $4 \%$ & $7 \%$ & $6 \%$ & $5 \%$ & $1 \%$ & $3 \%$ & $4 \%$ \\
\hline $\begin{array}{l}\text { External } \\
\text { migrants }\end{array}$ & $4 \%$ & $1 \%$ & $1 \%$ & $1 \%$ & $1 \%$ & $2 \%$ & $5 \%$ & $2 \%$ \\
\hline \multicolumn{8}{|c|}{1996} & \\
\hline Total & $100 \%$ & $100 \%$ & $100 \%$ & $100 \%$ & $100 \%$ & $100 \%$ & $100 \%$ & $100 \%$ \\
\hline Non-movers & $57 \%$ & $73 \%$ & $68 \%$ & $64 \%$ & $67 \%$ & $60 \%$ & $57 \%$ & $60 \%$ \\
\hline Movers & $43 \%$ & $27 \%$ & $32 \%$ & $36 \%$ & $33 \%$ & $40 \%$ & $43 \%$ & $40 \%$ \\
\hline $\begin{array}{l}\text { Non- } \\
\text { migrants }\end{array}$ & $23 \%$ & $15 \%$ & $16 \%$ & $21 \%$ & $18 \%$ & $21 \%$ & $23 \%$ & $26 \%$ \\
\hline Migrants & $20 \%$ & $12 \%$ & $16 \%$ & $15 \%$ & $14 \%$ & $18 \%$ & $20 \%$ & $14 \%$ \\
\hline $\begin{array}{l}\text { Internal } \\
\text { migrants }\end{array}$ & $17 \%$ & $12 \%$ & $15 \%$ & $14 \%$ & $13 \%$ & $16 \%$ & $16 \%$ & $12 \%$ \\
\hline $\begin{array}{l}\text { Intraprovi } \\
\text { ncial } \\
\text { migrants }\end{array}$ & $13 \%$ & $8 \%$ & $8 \%$ & $8 \%$ & $8 \%$ & $15 \%$ & $14 \%$ & $8 \%$ \\
\hline \begin{tabular}{l}
\multicolumn{1}{r}{ Interprovi } \\
ncial \\
migrants
\end{tabular} & $3 \%$ & $3 \%$ & $7 \%$ & $6 \%$ & $5 \%$ & $1 \%$ & $2 \%$ & $4 \%$ \\
\hline $\begin{array}{l}\text { External } \\
\text { migrants }\end{array}$ & $3 \%$ & $1 \%$ & $1 \%$ & $1 \%$ & $1 \%$ & $2 \%$ & $5 \%$ & $2 \%$ \\
\hline
\end{tabular}

Source: Table 1. 
TABLE 2 (cont.)

\section{Population 5 Years and Over, Showing Mobility Status}

(Percentage, Place of Residence 5 Years Ago)

For Canada, Provinces, and Territories, 1991 and 1996

\begin{tabular}{|c|c|c|c|c|c|}
\hline & Sask. & Alberta & $\begin{array}{c}\text { British } \\
\text { Columbia }\end{array}$ & Yukon & NW Terr. \\
\hline \multicolumn{6}{|l|}{1991} \\
\hline Total & $100 \%$ & $100 \%$ & $100 \%$ & $100 \%$ & $100 \%$ \\
\hline Non-movers & $61 \%$ & $47 \%$ & $44 \%$ & $35 \%$ & $35 \%$ \\
\hline Movers & $39 \%$ & $53 \%$ & $56 \%$ & $65 \%$ & $65 \%$ \\
\hline \begin{tabular}{|c|}
$\begin{array}{c}\text { Non- } \\
\text { migrants }\end{array}$ \\
\end{tabular} & $21 \%$ & $29 \%$ & $25 \%$ & $29 \%$ & $35 \%$ \\
\hline Migrants & $18 \%$ & $24 \%$ & $31 \%$ & $35 \%$ & $30 \%$ \\
\hline \begin{tabular}{|l|} 
Internal \\
migrants \\
\end{tabular} & $17 \%$ & $20 \%$ & $26 \%$ & $33 \%$ & $29 \%$ \\
\hline \begin{tabular}{|l|}
\multicolumn{1}{|c|}{ Intrapro } \\
vincial \\
migrants \\
\end{tabular} & $12 \%$ & $13 \%$ & $18 \%$ & $7 \%$ & $10 \%$ \\
\hline \begin{tabular}{|l|}
\multicolumn{1}{|c|}{ Interpro } \\
vincial \\
migrants \\
\end{tabular} & $4 \%$ & $7 \%$ & $8 \%$ & $26 \%$ & $19 \%$ \\
\hline $\begin{array}{c}\text { External } \\
\text { migrants }\end{array}$ & $1 \%$ & $3 \%$ & $5 \%$ & $2 \%$ & $1 \%$ \\
\hline \multicolumn{6}{|l|}{1996} \\
\hline Total & $100 \%$ & $100 \%$ & $100 \%$ & $100 \%$ & $100 \%$ \\
\hline Non-movers & $61 \%$ & $50 \%$ & $45 \%$ & $42 \%$ & $36 \%$ \\
\hline Movers & $39 \%$ & $50 \%$ & $55 \%$ & $58 \%$ & $64 \%$ \\
\hline \begin{tabular}{|c|}
$\begin{array}{c}\text { Non- } \\
\text { migrants }\end{array}$ \\
\end{tabular} & $21 \%$ & $29 \%$ & $25 \%$ & $29 \%$ & $38 \%$ \\
\hline Migrants & $17 \%$ & $21 \%$ & $29 \%$ & $29 \%$ & $26 \%$ \\
\hline \begin{tabular}{|c|} 
Internal \\
migrants
\end{tabular} & $16 \%$ & $18 \%$ & $23 \%$ & $28 \%$ & $25 \%$ \\
\hline \begin{tabular}{|l|}
\multicolumn{1}{|c|}{ Intrapro } \\
vincial \\
migrants \\
\end{tabular} & $11 \%$ & $12 \%$ & $16 \%$ & $6 \%$ & $9 \%$ \\
\hline \begin{tabular}{|l|}
\multicolumn{1}{|c|}{ Interpro } \\
vincial \\
migrants
\end{tabular} & $5 \%$ & $7 \%$ & $7 \%$ & $21 \%$ & $15 \%$ \\
\hline $\begin{array}{l}\text { External } \\
\text { migrants }\end{array}$ & $1 \%$ & $3 \%$ & $6 \%$ & $1 \%$ & \\
\hline
\end{tabular}




\section{TABLE 3}

\section{Population 1 Year and Over, Showing Mobility Status, 1996}

(Number and Percentage, Place of Residence 1 Year Ago)

\section{For Canada, Provinces, and Territories}

\begin{tabular}{|c|c|c|c|c|c|c|c|c|}
\hline \multicolumn{9}{|l|}{\begin{tabular}{|l|} 
Number \\
\end{tabular}} \\
\hline & Canada & Newfdld. & PEI & $\begin{array}{l}\text { Nova } \\
\text { Scotia }\end{array}$ & $\begin{array}{c}\text { New } \\
\text { Brunswick }\end{array}$ & Quebec & Ontario & Manitoba \\
\hline Total & $28,155,225$ & 541,630 & 131,050 & 888,835 & 721,070 & $6,958,710$ & $10,496,475$ & $1,084,900$ \\
\hline $\begin{array}{l}\text { External } \\
\text { migrants }\end{array}$ & 228,695 & 1,000 & 275 & 2,890 & 1,510 & 37,275 & 104,335 & 5,275 \\
\hline \begin{tabular}{l}
\multicolumn{2}{c}{ Interprovi } \\
ncial \\
migrants
\end{tabular} & 293,340 & 7,285 & 3,440 & 17,155 & 12,710 & 25,410 & 67,080 & 15,615 \\
\hline $\begin{array}{l}\text { Intraprovi } \\
\text { ncial } \\
\text { migrants }\end{array}$ & $1,290,150$ & 18,410 & 3,795 & 28,470 & 24,330 & 352,880 & 479,750 & 30,220 \\
\hline $\begin{array}{l}\text { Non- } \\
\text { migrants }\end{array}$ & $2,540,400$ & 32,440 & 8,890 & 77,920 & 55,760 & 537,505 & 896,995 & 108,975 \\
\hline Non-movers & $23,802,645$ & 482,490 & 114,650 & 762,395 & 626,760 & $6,005,650$ & $8,948,305$ & 924,815 \\
\hline \multicolumn{9}{|l|}{ Percentage } \\
\hline Total & $100.00 \%$ & $100.00 \%$ & $100.00 \%$ & $100.00 \%$ & $100.00 \%$ & $100.00 \%$ & $100.00 \%$ & $100.00 \%$ \\
\hline $\begin{array}{l}\text { External } \\
\text { migrants }\end{array}$ & $0.81 \%$ & $0.18 \%$ & $0.21 \%$ & $0.33 \%$ & $0.21 \%$ & $0.54 \%$ & $0.99 \%$ & $0.49 \%$ \\
\hline $\begin{array}{l}\text { Interprovi } \\
\text { ncial } \\
\text { migrants }\end{array}$ & $1.04 \%$ & $1.35 \%$ & $2.62 \%$ & $1.93 \%$ & $1.76 \%$ & $0.37 \%$ & $0.64 \%$ & $1.44 \%$ \\
\hline $\begin{array}{l}\text { Intraprovi } \\
\text { ncial } \\
\text { migrants }\end{array}$ & $4.58 \%$ & $3.40 \%$ & $2.90 \%$ & $3.20 \%$ & $3.37 \%$ & $5.07 \%$ & $4.57 \%$ & $2.79 \%$ \\
\hline $\begin{array}{l}\text { Non- } \\
\text { migrants }\end{array}$ & $9.02 \%$ & $5.99 \%$ & $6.78 \%$ & $8.77 \%$ & $7.73 \%$ & $7.72 \%$ & $8.55 \%$ & $10.04 \%$ \\
\hline Non-movers & $84.54 \%$ & $89.08 \%$ & $87.49 \%$ & $85.77 \%$ & $86.92 \%$ & $86.30 \%$ & $85.25 \%$ & $85.24 \%$ \\
\hline
\end{tabular}

Source: Statistics Canada 
TABLE 3 (Cont.)

Population 1 Year and Over, Showing Mobility Status, 1996 (Number and Percentage, Place of Residence 1 Year Ago)

For Canada, Provinces, and Territories

\begin{tabular}{|l|r|r|r|r|r|}
\hline Number & Sask. & Alberta & $\begin{array}{c}\text { British } \\
\text { Columbia }\end{array}$ & Yukon & NW Terr. \\
\hline Total & 963,305 & $2,631,835$ & $3,644,505$ & 30,220 & 62,680 \\
\hline $\begin{array}{c}\text { External } \\
\text { migrants }\end{array}$ & 3,675 & 18,730 & 53,415 & 170 & 140 \\
\hline $\begin{array}{c}\text { Interpro } \\
\text { vincial } \\
\text { migrants }\end{array}$ & 18,255 & 54,690 & 66,205 & 2,360 & 3,130 \\
\hline $\begin{array}{c}\text { Intrapro } \\
\text { vincial } \\
\text { migrants }\end{array}$ & 40,300 & 112,285 & 196,280 & 745 & 2,670 \\
\hline $\begin{array}{l}\text { Non- } \\
\text { migrants }\end{array}$ & 90,235 & 310,395 & 406,395 & 4,095 & 10,795 \\
\hline \begin{tabular}{l} 
Non-movers \\
\hline $\begin{array}{l}\text { Percentage } \\
\text { Total }\end{array}$
\end{tabular} & 810,840 & $2,135,735$ & $2,922,205$ & 22,855 & 45,945 \\
\hline $\begin{array}{c}\text { External } \\
\text { migrants }\end{array}$ & $100.00 \%$ & $100.00 \%$ & $100.00 \%$ & $100.00 \%$ & $100.00 \%$ \\
\hline $\begin{array}{c}\text { Interpro } \\
\text { vincial } \\
\text { migrants }\end{array}$ & $1.90 \%$ & $2.08 \%$ & $1.82 \%$ & $7.81 \%$ & $4.99 \%$ \\
\hline $\begin{array}{c}\text { Intrapro } \\
\text { vincial } \\
\text { migrants }\end{array}$ & $4.18 \%$ & $4.27 \%$ & $5.39 \%$ & $2.47 \%$ & $4.26 \%$ \\
\hline $\begin{array}{l}\text { Non- } \\
\text { migrants }\end{array}$ & $9.37 \%$ & $11.79 \%$ & $11.15 \%$ & $13.55 \%$ & $17.22 \%$ \\
\hline $\begin{array}{l}\text { Non-movers } \\
\text { Non }\end{array}$ & $84.17 \%$ & $81.15 \%$ & $80.18 \%$ & $75.63 \%$ & $73.30 \%$ \\
\hline
\end{tabular}




\section{TABLE 4}

\section{Inter-Regional Migration in the United States, 1980--2000 Selected Years}

\begin{tabular}{|c|c|c|c|c|}
\hline Mobility period and type & Northeast & Midwest & South & West \\
\hline \multicolumn{5}{|l|}{\begin{tabular}{|l|}
$1999-2000$ \\
\end{tabular}} \\
\hline Inmigrants.......................... & 363 & 722 & 1,258 & 763 \\
\hline Outmigrants............................. & 615 & 640 & 1,031 & 820 \\
\hline Net internal migration............... & -252 & 82 & 227 & -57 \\
\hline Movers from abroad... & 292 & 238 & 612 & 604 \\
\hline Net migration (including abroad).. & 40 & 320 & 839 & 547 \\
\hline Population & 53594 & 64393 & 100237 & 63198 \\
\hline \multicolumn{5}{|l|}{$1989-90$} \\
\hline Inmigrants.. & 461 & 908 & 1,428 & 964 \\
\hline Outmigrants................. & 758 & 1,024 & 1,198 & 781 \\
\hline Net internal migration................. & -297 & -116 & 230 & 183 \\
\hline Movers from abroad................... & 328 & 169 & 500 & 562 \\
\hline Net migration (including abroad).... & 31 & 53 & 730 & 745 \\
\hline Population & 50809 & 59668 & 85446 & 52786 \\
\hline \multicolumn{5}{|l|}{$1980-81$} \\
\hline Inmigrants..... & 464 & 650 & 1,377 & 871 \\
\hline Outmigrants......................... & 706 & 1,056 & 890 & 710 \\
\hline Net internal migration................. & -242 & -406 & 487 & 161 \\
\hline Movers from abroad... & 207 & 180 & 412 & 514 \\
\hline Net migration (including abroad).... & -35 & -226 & 899 & 675 \\
\hline Population & 49137 & 58867 & 75367 & 43171 \\
\hline
\end{tabular}

Source: US Bureau of the Census. All figures in thousands. 
TABLE 5

\section{Migration Rates in the United States, 1980--2000 Selected Years}

\begin{tabular}{|c|c|c|c|c|}
\hline Mobility period and type & Northeast & Midwest & South & West \\
\hline \multicolumn{5}{|l|}{ 1999-2000 } \\
\hline Inmigrants.. & $0.68 \%$ & $1.12 \%$ & $1.26 \%$ & $1.21 \%$ \\
\hline Outmigrants.. & $1.15 \%$ & $0.99 \%$ & $1.03 \%$ & $1.30 \%$ \\
\hline Net internal migration................. & $-0.47 \%$ & $0.13 \%$ & $0.23 \%$ & $-0.09 \%$ \\
\hline Movers from abroad........... & $0.54 \%$ & $0.37 \%$ & $0.61 \%$ & $0.96 \%$ \\
\hline \begin{tabular}{|l} 
Net migration (including abroad)....... \\
\end{tabular} & $0.07 \%$ & $0.50 \%$ & $0.84 \%$ & $0.87 \%$ \\
\hline & & & & \\
\hline Gross Internal Migration Rate & $1.82 \%$ & $2.12 \%$ & $2.28 \%$ & $2.50 \%$ \\
\hline Gross/Net Internal Migration Rate & -3.88 & 16.61 & 10.08 & -27.77 \\
\hline \multicolumn{5}{|l|}{$1989-90$} \\
\hline Inmigrants.. & $0.91 \%$ & $1.52 \%$ & $1.67 \%$ & $1.83 \%$ \\
\hline Outmigrants... & $1.49 \%$ & $1.72 \%$ & $1.40 \%$ & $1.48 \%$ \\
\hline Net internal migration................. & $-0.58 \%$ & $-0.19 \%$ & $0.27 \%$ & $0.35 \%$ \\
\hline 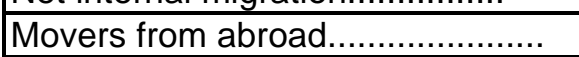 & $0.65 \%$ & $0.28 \%$ & $0.59 \%$ & $1.06 \%$ \\
\hline \begin{tabular}{|l} 
Net migration (including abroad). \\
\end{tabular} & $0.06 \%$ & $0.09 \%$ & $0.85 \%$ & $1.41 \%$ \\
\hline Gross Internal Migration Rate & $2.40 \%$ & $3.24 \%$ & $3.07 \%$ & $3.31 \%$ \\
\hline Gross/Net Internal Migration Rate & -4.10 & -16.66 & 11.42 & 9.54 \\
\hline \multicolumn{5}{|l|}{$1980-81$} \\
\hline Inmigrants... & $0.94 \%$ & $1.10 \%$ & $1.83 \%$ & $2.02 \%$ \\
\hline Outmigrants... & $1.44 \%$ & $1.79 \%$ & $1.18 \%$ & $1.64 \%$ \\
\hline Net internal migration......... & $-0.49 \%$ & $-0.69 \%$ & $0.65 \%$ & $0.37 \%$ \\
\hline Movers from abroad....................... & $0.42 \%$ & $0.31 \%$ & $0.55 \%$ & $1.19 \%$ \\
\hline Net migration (including abroad)...... & $-0.07 \%$ & $-0.38 \%$ & $1.19 \%$ & $1.56 \%$ \\
\hline Gross Internal Miaration Rate & $2.38 \%$ & $2.90 \%$ & $3.01 \%$ & $3.66 \%$ \\
\hline Gross/Net Internal Migration Rate & -4.83 & -4.20 & 4.66 & 9.82 \\
\hline
\end{tabular}

Source: Table 4. 
TABLE 6

Frequency of Moves between 1979 and 1996

By Educational Attainment, NLSY Sample

\begin{tabular}{|l|r|r|r|r|r|}
\hline Percent Moving per Period (a) & $\begin{array}{l}\text { High School } \\
\text { Dropout }\end{array}$ & $\begin{array}{l}\text { High School } \\
\text { Only }\end{array}$ & $\begin{array}{l}\text { Some } \\
\text { College }\end{array}$ & $\begin{array}{l}\text { lollege } \\
\text { Graduate } \\
\text { Only }\end{array}$ & $\begin{array}{l}\text { More Than } \\
\text { College } \\
\text { Graduate }\end{array}$ \\
\hline Betwween States & 5.3 & 5.3 & 6.4 & 8.7 & 10.2 \\
\hline Between Noncontiguous States & 3.6 & 4 & 4.7 & 6 & 7.6 \\
\hline Between Census Divisions & 3.5 & 4.1 & 4.7 & 6.3 & 7.8 \\
\hline
\end{tabular}

Source: Kodrzycki (2001), Table 2, based on National Longitudinal Survey of Youth.

(a) Annually, except for period 1994-1996. 


\section{TABLE 7}

\section{Five-Year Migration Rates across Census Divisions, College Graduates 1979 to 1991, NLSY Sample}

\section{A. By High School Location}

\begin{tabular}{|l|r|r|r|}
\hline Census Division & $\begin{array}{l}\text { Domestic } \\
\text { In-Migration }\end{array}$ & $\begin{array}{l}\text { Domestic } \\
\text { Out-Migration }\end{array}$ & $\begin{array}{l}\text { Domestic } \\
\text { Net Migration }\end{array}$ \\
\hline New England & 19.5 & 29.9 & -10.4 \\
\hline Middle Atlantic & 19.3 & 20.5 & -1.2 \\
\hline East North Central & 9.8 & 25.6 & -15.9 \\
\hline West North Central & 13.2 & 27.4 & -14.2 \\
\hline South Atlantic & 32.9 & 19.2 & 13.8 \\
\hline East South Central & 23.5 & 35.3 & -11.8 \\
\hline West South Central & 23.6 & 19.4 & 4.2 \\
\hline Mountain & 69.4 & 36.1 & 33.3 \\
\hline Pacific & 52.6 & 10.5 & 42.1 \\
\hline United States & 23.5 & 23.5 & 0 \\
\hline
\end{tabular}

\section{B. By College Location}

\begin{tabular}{|l|r|r|r|}
\hline Census Division & $\begin{array}{l}\text { Domestic } \\
\text { In-Migration }\end{array}$ & $\begin{array}{l}\text { Domestic } \\
\text { Out-Migration }\end{array}$ & $\begin{array}{l}\text { Domestic } \\
\text { Net Migration }\end{array}$ \\
\hline New England & 16.4 & 20.5 & -4.1 \\
\hline Middle Atlantic & 15.6 & 13.8 & 1.8 \\
\hline East North Central & 17.3 & 23.2 & -5.9 \\
\hline West North Central & 14.7 & 25.5 & -10.8 \\
\hline South Atlantic & 27.5 & 15 & 12.6 \\
\hline East South Central & 21.3 & 25.5 & -4.3 \\
\hline West South Central & 10.9 & 28.3 & -17.4 \\
\hline Mountain & 42.5 & 25 & 17.5 \\
\hline Pacific & 26.3 & 11.6 & 14.7 \\
\hline United States & 19.8 & 19.8 & 0 \\
\hline
\end{tabular}

Sample Size $=1003$ 
TABLE 8

Revenues of Canadian Universities, 1994--199

\begin{tabular}{|l|r|r|r|}
\hline & $1994 / 95$ & $1998 / 99$ & $1999 / 2000$ \\
\hline Total revenue & $100.0 \%$ & $100.0 \%$ & $100.0 \%$ \\
\hline Government grants and contracts & & & \\
\hline Federal & $9.1 \%$ & $8.3 \%$ & $8.9 \%$ \\
\hline Provincial & $53.3 \%$ & $46.2 \%$ & $45.3 \%$ \\
\hline Municipal and other & $0.4 \%$ & $0.7 \%$ & $0.7 \%$ \\
\hline Total & $62.8 \%$ & $55.2 \%$ & $55.0 \%$ \\
\hline Student fees & & & \\
\hline Bequests, donations, non-gov't grants/contracts & $16.0 \%$ & $20.3 \%$ & $19.3 \%$ \\
\hline Sales of services and products & $8.0 \%$ & $9.7 \%$ & $9.5 \%$ \\
\hline Investment revenue & $8.6 \%$ & $8.4 \%$ & $9.1 \%$ \\
\hline Miscellaneous & $2.6 \%$ & $3.5 \%$ & $3.7 \%$ \\
\hline
\end{tabular}




\section{IZA Discussion Papers}

\begin{tabular}{|c|c|c|c|c|}
\hline No. & Author(s) & Title & Area & Date \\
\hline 875 & C. Grund & $\begin{array}{l}\text { Severance Payments for Dismissed Employees } \\
\text { in Germany }\end{array}$ & 3 & $09 / 03$ \\
\hline 876 & $\begin{array}{l}\text { M. Karanassou } \\
\text { H. Sala } \\
\text { D. J. Snower }\end{array}$ & $\begin{array}{l}\text { The European Phillips Curve: Does the NAIRU } \\
\text { Exist? }\end{array}$ & 3 & $09 / 03$ \\
\hline 877 & M.-S. Yun & Decomposing Differences in the First Moment & 3 & $09 / 03$ \\
\hline 878 & $\begin{array}{l}\text { J. T. Addison } \\
\text { C. Schnabel } \\
\text { J. Wagner }\end{array}$ & $\begin{array}{l}\text { The Course of Research into the Economic } \\
\text { Consequences of German Works Councils }\end{array}$ & 3 & $09 / 03$ \\
\hline 879 & $\begin{array}{l}\text { A. Constant } \\
\text { Y. Shachmurove }\end{array}$ & $\begin{array}{l}\text { Entrepreneurial Ventures and Wage Differentials } \\
\text { Between Germans and Immigrants }\end{array}$ & 1 & $09 / 03$ \\
\hline 880 & $\begin{array}{l}\text { W. Koeniger } \\
\text { A. Vindigni }\end{array}$ & $\begin{array}{l}\text { Employment Protection and Product Market } \\
\text { Regulation }\end{array}$ & 2 & $10 / 03$ \\
\hline 881 & R. A. Hart & $\begin{array}{l}\text { Worker-Job Matches, Job Mobility, and Real } \\
\text { Wage Cyclicality }\end{array}$ & 1 & $10 / 03$ \\
\hline 882 & $\begin{array}{l}\text { A. Lindbeck } \\
\text { D. J. Snower }\end{array}$ & The Firm as a Pool of Factor Complementarities & 5 & $10 / 03$ \\
\hline 883 & $\begin{array}{l}\text { S. Groeneveld } \\
\text { J. Hartog }\end{array}$ & $\begin{array}{l}\text { Overeducation, Wages and Promotions within } \\
\text { the Firm }\end{array}$ & 5 & $10 / 03$ \\
\hline 884 & $\begin{array}{l}\text { J. Masso } \\
\text { A. Heshmati }\end{array}$ & $\begin{array}{l}\text { The Optimality and Overuse of Labour in } \\
\text { Estonian Manufacturing Enterprises }\end{array}$ & 4 & $10 / 03$ \\
\hline 885 & $\begin{array}{l}\text { A. Constant } \\
\text { K. F. Zimmermann }\end{array}$ & $\begin{array}{l}\text { The Dynamics of Repeat Migration: A Markov } \\
\text { Chain Analysis }\end{array}$ & 1 & $10 / 03$ \\
\hline 886 & $\begin{array}{l}\text { J. J. Dolado } \\
\text { M. Jansen } \\
\text { J. F. Jimeno }\end{array}$ & $\begin{array}{l}\text { On-the-Job Search in a Matching Model with } \\
\text { Heterogenous Jobs and Workers }\end{array}$ & 1 & $10 / 03$ \\
\hline 887 & $\begin{array}{l}\text { B. Irlenbusch } \\
\text { D. Sliwka }\end{array}$ & $\begin{array}{l}\text { Transparency and Reciprocal Behavior in } \\
\text { Employment Relations }\end{array}$ & 7 & $10 / 03$ \\
\hline 888 & W. Koeniger & $\begin{array}{l}\text { Collective Dismissal Cost, Product Market } \\
\text { Competition and Innovation }\end{array}$ & 3 & $10 / 03$ \\
\hline 889 & D. E. Wildasin & $\begin{array}{l}\text { Fiscal Policy, Human Capital, and Canada-US } \\
\text { Labor Market Integration }\end{array}$ & 2 & $10 / 03$ \\
\hline
\end{tabular}

An updated list of IZA Discussion Papers is available on the center's homepage www.iza.org. 